Board of Governors of the Federal Reserve System

International Finance Discussion Papers

Number 778

September 2003

\title{
CAPITAL CONTROLS AND THE INTERNATIONAL \\ TRANSMISSION OF U.S. MONEY SHOCKS
}

Jacques Miniane and John H. Rogers

NOTE: International Finance Discussion Papers are preliminary materials circulated to stimulate discussion and critical comment. References in publications to International Finance Discussion Papers (other than an acknowledgment that the writer has had access to unpublished material) should be cleared with the author or authors. Recent IFDPs are available on the Web at www.federalreserve.gov/pubs/ifdp/. 


\title{
Capital Controls and the International Transmission of U.S. Money Shocks
}

\author{
Jacques Miniane John H. Rogers*
}

July 10, 2003

\begin{abstract}
In this paper we assess whether capital controls effectively insulate countries from U.S. monetary shocks, looking simultaneously at a large range of country experiences in a unified estimation framework. We estimate the effect of identified U.S. monetary shocks on the exchange rate and foreign country interest rates, and test whether countries with less open capital accounts exhibit systematically smaller responses. We find essentially no evidence in favor of this notion. Other country factors such as the exchange rate regime or degree of dollarization explain more of the cross-country differences in responses. The significant differences in responses we do find are more pronounced at short horizons.

JEL classification: F32, F34
\end{abstract}

\section{Introduction}

The question of whether the existing "architecture" of the world financial system can cope with the size and nature of modern-day capital flows has once again come with force to the attention of policymakers and academics. Key to the resurgence of interest is the late 1990's crises in Asia, Russia and Brazil, aided by the perception that Malaysia avoided a harsher fate

\footnotetext{
${ }^{*}$ Miniane: Department of Economics, Johns Hopkins University. Rogers: Board of Governors of the Federal Reserve System. Email: jminiane@att.net and john.h.rogers@frb.gov. The authors wish to thank Kirran Bari for assistance with the data and Matt Shum, Jonathan Wright, and seminar participants at Johns Hopkins University, the Inter American Development Bank and the International Finance Division of the Federal Reserve Board for useful comments and suggestions. The views in this paper are solely the responsibility of the authors and should not be interpreted as reflecting the views of the Board of Governors of the Federal Reserve System, or of other members of its staff.
} 
by imposing controls on capital outflows. The recent fallout in Argentina following a decade of capital account liberalization suggests that the debate on capital controls is not likely to die soon, whether or not open capital accounts had much to do with Argentina's problems.

A vast academic literature surveying a wide range of experiences with capital controls has yet to produce consensus on their effectiveness (Dooley (1996) and Eichengreen (2002) provide overviews). One strand of the literature undertakes cross-sectional studies, typically dealing with the relationship between capital controls and real variables such as investment and growth. Rodrik (1998) finds no evidence of a positive correlation between capital account openness and growth or investment/GDP ratios, and argues against capital account convertibility: given the periodicity and devastating power of financial crises, it is not wise to remove capital controls since, at worst, they don't seem to affect welfare. Quinn (1997) and Edwards (2001) reach the opposite conclusion, using a different measure of capital controls developed by Quinn (see Grilli and Milesi-Ferretti (1995) also).

Some studies have looked for the effects of capital controls in places other than output. Chinn and Ito (2002) find that financial development, measured by private credit creation and stock market capitalization, is negatively correlated with the extent of capital controls, a correlation that is stronger in developed countries with solid institutional frameworks. Desai, Foley, and Hines (2003) use the Bureau of Economic Analysis annual survey of U.S. Direct Investment Abroad to study the impact of host countries' capital controls on U.S. multinationals corporate finance decisions. The authors find that controls do matter: affiliates in countries with less open capital accounts are smaller in size, overinvest in capital assets to the detriment of financial assets, tend to rely more heaviliy on initial parent equity infusions or on retained earnings rather than on debt financing to avoid higher borrowing costs, and use intra-firm pricing to evade controls on profit remittances. An IMF collection of fourteen country case studies involving capital account liberalization (Ariyoshi et al. (2000)) concludes that capital controls cannot act as a substitute for sound macroeconomic policy, but also acknowledges that controls cannot be easily dismissed as a buffer to external shocks or to provide breathing space in which to adopt sound policy.

Lacking consensus on how to best measure capital account openness and how to define "effectiveness", a second strand of the literature on capital controls has taken a case study approach. Researchers focus on a well identified sequence of events, comparing the behavior of relevant variables such 
as exchange rates, interest rates, or capital flows after the imposition or removal of controls. Consider the case of Malaysia, which imposed controls in September 1998, and whose exchange rate, interest rate (T-bill) and foreign reserves are displayed in Figure 1. Reserves, which had fallen substantially before September, started rising immediately and promptly returned to precrisis levels. The exchange rate was eventually stabilized and interest rates fell (though this started a bit before the imposition of controls). More formal analysis of Malaysia's experience by Kaplan and Rodrik (2001) and Edison and Reinhart (2001) find that, as suggested by Figure 1, capital controls had indeed been effective. Chile's unremunerated reserve requirement (URR), designed to discourage short-term flows in favor of long term investments, is examined by Cardoso and Laurens (1998) and de Gregorio et al. (2000). Both studies find that the URR has tilted the composition of flows towards longer maturities, but has had little effect on interest rate differentials and the real exchange rate. ${ }^{1}$

The question we ask in this paper is whether the apparent effectiveness of capital controls is confined to particular experiences like Malaysia and Chile, as the case-study literature suggests, or is a more general phenomenon. We examine whether more stringent capital controls better insulate countries from foreign monetary shocks. Although this metric of "effectiveness" is an implication of almost any theoretical model that incorporates restrictions on capital flows, we are not aware that it has been examined in the crosscountry literature. Our notion of effectiveness is not the only relevant one, but it does allow us to look systematically across a large number of country experiences, including emerging markets and industrialized countries. Using standard tools from the VAR literature, we estimate the response of the foreign (i.e., non-U.S.) interest rate and the exchange rate to an identified U.S. monetary policy shock. ${ }^{2}$ We then test whether those responses are smaller

\footnotetext{
${ }^{1}$ Other papers in the case-study vein focus on how well controls are able to sustain dual exchange rate regimes. Gros (1988) finds a wedge between dual rates in 1980s Belgium and Mexico that lasts for about six months. A similar finding applies to returns on domestic bank deposits with similar deposits offered by off-shore branches (Gros (1987)). Studies concentrating on currency or balance of payments crises such as Fieleke (1994) or Edison and Reinhart (2001) find that countries which impose controls in the midst of a crisis may in some cases reduce the volatiliy of interest rates while trying to defend their currency, but typically cannot avoid a realignment in the end.

${ }^{2}$ This is not the only type of disturbance we could consider. It would be interesting to extend this analysis to, e.g., terms-of-trade shocks. The advantage of our approach is that the identification of (U.S.) monetary policy shocks has been studied much more than other types of shocks. Thus, there is something of a consensus (or at least a roadmap) in the literature, relative to identification of other types of disturbances.
} 
for countries with more stringent capital controls. We consider different response horizons, from six and twelve months up to 48 months. Because a country's interest rate and exchange rate responses might differ on the basis of factors other than the degree of capital controls, we also control for the type of exchange rate arrangement, degree of liability dollarization, and degree of trade integration with the United States.

We find virtually no evidence that capital controls are effective in this sense. We do find some evidence that the exchange rate response to a U.S. monetary policy shock is significantly smaller in countries with more stringent capital controls, but the effect is not large and not robust, as it goes away at horizons greater than one year and/or when we control for the additional country characteristics. We find little evidence that the interest rate response is smaller for countries with high capital controls. The exchange rate regime and degree of liability dollarization are significant in determining how exchange rates and interest rates respond to the shock, in the way predicted by theory.

In the next section we describe the empirical strategy and data used in the paper. We present results in section 3, and discuss the implications of those results in the final section.

\section{Empirical Strategy and Data}

Key to our estimation work is properly identifying U.S. monetary policy shocks. The current predominant approach is to use structural vector autoregression (VAR) techniques. Researchers have traditionally relied on assuming a recursive structure to the system and using a priori restrictions, either on the contemporaneous or long-run relationship between variables. ${ }^{3}$ We follow in the traditional, "short-run restrictions" vein.

Assume the economy is represented by the following model:

$$
A(L) Y_{t}=e_{t}
$$

\footnotetext{
${ }^{3}$ Open economy applications taking the traditional approach include Clarida and Gali (1994), Eichenbaum and Evans (1995), and Rogers (1999), while Kim and Roubini (2000)) use short-run restrictions but do not rely exclusively on a recursive structure. More recent contributions include Faust and Rogers (2003) and Faust, Rogers, Swanson and Wright (2002), which are discussed below.
} 
where $Y_{t}$ is an $(n \times 1)$ vector of data, $e_{t}$ is a $(n \times 1)$ vector of strucutural shocks, and $\mathrm{A}(\mathrm{L})$ is a $(n \times n)$ matrix whose typical element is a polynomial in the lag operator. The shocks are assumed to be serially and mutually uncorrelated. Since the matrix of contemporaneous relations between variables $A(0)$ need not be diagonal, one cannot estimate this model.

The estimable reduced form version of the model is:

$$
\begin{aligned}
B(L) Y_{t} & =u_{t} \\
\text { where } B(L) & =A(0)^{-1} \times A(L) \\
u_{t} & =A(0)^{-1} \times e_{t}
\end{aligned}
$$

$U_{t}$ is the vector of errors in the reduced-form equations. If one knew $A(0)$ then the parameters in the structural model and the structural shocks could be recovered by estimating this reduced form. Notice that if one normalizes the structural model for the shocks $e_{t}$ to have unit variance, then:

$$
\Omega=A(0)^{-1} \times\left(A(0)^{-1}\right)^{\prime}
$$

where $\Omega$ is the estimable variance-covariance matrix of reduced-form errors. Given that $\Omega$ contains $n(n+1) / 2$ free parameters, identifying $A(0)$ requires imposing $n(n-1) / 2$ restrictions.

We concentrate on a benchmark eight-variable model including an index of commodity prices (CP), U.S. industrial production (Y), U.S. consumer prices $(\mathrm{P})$, foreign industrial production $\left(\mathrm{Y}^{*}\right)$, foreign 3-month interest rate $\left(\mathrm{R}^{*}\right)$, the U.S. Federal Funds Rate (FFR), the ratio of non-borrowed reserves to total reserves in the U.S. (M), and the nominal exchange rate with the U.S. dollar (S). This model adds commodity prices to the 7-variable model estimated by Eichenbaum and Evans (1995). In our "baseline" identification, we impose the following recursive ordering on the variables: $\left[\mathrm{CP}, \mathrm{Y}, \mathrm{P}, \mathrm{Y}^{*}\right.$, $\left.\mathrm{R}^{*}, \mathrm{FFR}, \mathrm{M}, \mathrm{S}\right]$. In this setting, an exogenous monetary shock is identified as an orthogonal shock to the Fed Funds Rate, normalized to be positive (contractionary money shock) and equal to 25 basis points on impact.

Practitioners and critics alike acknowledge that the traditional approach to identification of structural monetary policy shocks is contentious. There are an insufficient number of uncontroversial assumptions available to fully identify standard-sized open economy VARs. Faust and Rogers (2003) apply an approach to identification, originally developed by Faust (1998), that allows one to do inference in partially-identified models. They investigate 
the sensitivity of various results in the literature to implausible identifying assumptions. Unfortunately, the results of interest are often found to be sensitive to the identification scheme. ${ }^{4}$ In a related vein, Faust, Rogers, Swanson, and Wright (2002) bring high-frequency data to the identification problem, imposing that the impulse responses of the exchange rate and interest rates in the VAR match the responses estimated from high-frequency financial market data. Motivated by this, we examine the sensitivity of our conclusions to different identification schemes.

One could argue that applying any particular statistical model to a diverse set of countries is unwarranted. This criticism should be weighed against the desirability of identifying a shock that is common for all countries under consideration. As discussed in the results below, this is something we seem to have achieved. While case studies allow for greater tailoring of the statistical model to the specific event under study, they preclude the kind of statistical inference presented in this paper and in the cross-country studies discussed above. Ultimately, one can get a complete picture about the effectiveness of capital controls only after considering both types of evidence.

\subsection{Data}

We study twenty-six countries covering a wide spectrum in terms of capital account restrictions, economic development, geographic location, exchange rate regime, etc. ${ }^{5}$ Our VARs are monthly and span the period 1975:1 to 1998:12. As is common practice in monthly VARs we impose six lags in the estimation. All variables are expressed in logs except for interest rates. An important factor motivating our choice of countries is the desire to have better measures of capital controls than the crude zero/one dummy published by the International Financial Statistics (IFS) of the IMF until 1996. The

\footnotetext{
${ }^{4}$ For example, Eichenbaum and Evans (1995) find that monetary policy shocks induce large deviations from uncovered interest parity and dollar appreciations that peak as late as two to three years after the shock - so-called delayed overshooting. Faust and Rogers (2003) find that although the first result is highly robust to identification, delayed overshooting is very sensitive to allowing simultaneity among asset market variables. In addition, papers estimating the share of monetary policy shocks in accounting for exchange rate variability report estimates ranging from a few percentage points to more than half (Clarida and Gali (1994), Eichenbaum and Evans (1995), and Rogers (1999)).

${ }^{5}$ The countries are, in alphabetical order: Australia, Austria, Belgium, Canada, Chile, Colombia, Denmark, Finland, France, Germany, Greece, India, Italy, Japan, Korea, Malaysia, Mexico, The Netherlands, Norway, The Philippines, Portugal, South Africa, Spain, Sweden, Turkey, and the United Kingdom.
} 
choice of countries, and in particular the desire to preserve a reasonablysized sample of countries (which includes nine of the original eleven euro area members), in turn dictates our ending the sample period in 1998:12. With the launch of the euro, the exchange rates and interest rates of nine out of our 26 countries became one, making it impossible to consider them independent cross-sectional observations after 1998:12.

We exploit a new set of measures of capital controls restrictions developed by Miniane (2000). The indexes use publicly available information contained in the Exchange Arrangements and Exchange Restrictions publication of the IMF to extend back to 1983 the IMF's post-1996 practice of reporting dummies in twelve different categories of capital transactions. ${ }^{6}$ Before 1996, the IMF only reported a single zero/one dummy for capital account restrictions. Miniane (2000) shows in detail how the more disaggregated measure captures several episodes of capital account liberalization that are not picked up by pre-1996 IFS data. Miniane (2000) also adds information on dual exchange rates. In the current paper, we use as our capital controls measure the average of the dummies over all categories and all years for each country. ${ }^{7}$

To reduce the chance of making spurious inferences about the effectiveness of capital controls, we also account for other variables that could explain differences in responses to U.S. shocks. We concentrate on three such "country factors": the exchange rate regime, degree of dollarization, and degree of trade integration with the United States.

The exchange rate regime is classified using information from IFS. We assign countries to one of four categories, where a higher index denotes a more flexible regime. Pure peg regimes are category one. Limited flexibility regimes, category two, include pegs to baskets including the U.S. dollar or binding bands of no more than plus or minus $7.5 \%$ around the central parity. Managed floats comprise category three and pure floating regimes is the

\footnotetext{
${ }^{6}$ The twelve categories are: Capital Market Securities, Money Market Instruments, Collective Investment Securities, Derivatives and Other Instruments, Commercial Credits, Financial Credits, Guarantees and Financial Back-Up Securities, Direct Investment, Repatriation of Profits or Liquidation of Direct Investment, Real Estate, Specific Provisions to Commercial Banks and Other Credit Institutions, and Specific Provisions to Institutional Investors.

${ }^{7}$ We also construct a sub-index using only the first four and the last three categories which are more directly concerned with asset markets; the correlation between the two is 0.93. We do not report any results with the sub-index.
} 
final category. ${ }^{8}$ The country index is obtained by averaging this data over the period 1975-1998. Some studies such as Levy Yeyati and Sturzenegger (1999) and Reinhart and Rogoff (2002) have criticized the IFS exchange regime data for being a de jure and not de facto classification. We also utilize an index based on Reinhart and Rogoff. The sample correlation with our IFS-based index is above 0.6 , as seen in Table 1 , and estimation results were not much changed when we used these instead.

The degree of dollarization in the country is measured by the share of the country's banking sector claims that are denominated in U.S. dollars. Several studies, including Aghion et al. (2000) and Hausmann et al. (2001), have stressed that foreign currency liabilities are an important explanation why countries with de jure floats may work hard to smooth exchange rate fluctuations. Finally, trade openness is measured as the sum of exports to the U.S. and imports from the U.S., as a share of the country's GDP. All data sources are detailed in the appendix.

Table 1 shows the value of each country factor together with their sample correlations. As expected, developed nations tend to have more open capital accounts on average, with the U.K. the least restrictive. Chile stands at the other extreme. Even though the correlation between the Miniane (2000) and the traditional IFS measures is high, there are important differences between the two. Whereas several countries are reported as having no controls in any year according to IFS measure, this never happens in the new measure. At the other extreme, only Chile is classified by the Miniane (2000) measure as having a value of one for all years, whereas nine countries do so according to the traditional measure. As a result, there is much more clustering of countries at the extremes in the IFS measure. In addition, note that there is a large negative correlation between the exchange rate regime and the capital controls index, perhaps because countries with pegs resort to capital controls in an attempt to gain some monetary policy independence. The dollarization and trade integration measures are as expected: countries in the Americas display higher trade integration with the US and higher liability dollarization than European countries, with Asia being a middle ground.

\footnotetext{
${ }^{8}$ We slightly modify IFS information to reflect the fact that we are interested in responses vis-a-vis U.S. shocks: for instance, we categorize France or Germany as pure floats even though the IFS assigns them to the "cooperative agreements" category.
} 


\subsection{Panel VARs}

As a first approach to estimation, we separate countries in two groups depending on whether they have high or low levels of capital controls, fixed or floating exchange rate regimes, high or low levels of dollarization, and high or low levels of trade integration with the United States. We separate countries in a straightforward manner. For capital controls, we group countries according to whether their index is below or above 0.5. This leads to groups of 12 (low controls) and 14 (high controls) countries initially (and eventually 12 and 12 when we ultimately exclude Mexico and Turkey). For the other variables, we simply sort countries by ascending level of the relevant variable and divide the sample in two.

For each sub-group, we estimate our benchmark eight-variable model in a panel setting, imposing a common constant and common coefficients among countries in the sub-group. We then compute impulse responses to an identified U.S. monetary shock and check whether we can detect significant differences between the two groups in their foreign interest rate and exchange rate responses.

\subsection{Bilateral VARs}

The panel approach has an advantage in its ease of exposition, but is limited in that it allows us to make inferences about the importance of only one country factor at a time. Furthermore, separating the sample in two is a rather crude way to assess the effect of the country factor on the transmission of U.S. shocks. Thus, we also estimate VARs for each country separately, and compute the cumulative exchange rate and interest rate responses. We then regress the country-specific responses at horizons six, twelve, twentyfour, and forty-eight months on the (country-specific) values of the capital controls index, exchange rate regime dummy, degree of dollarization, and degree of trade integration with the United States. We refer to the latter as our "second stage" regressions.

One can deduce the expected sign of the relationships as follows. ${ }^{9}$ If capital controls have an effect on short-term capital flows, then countries with such controls could keep interest rates low following a contractionary U.S. shock without suffering a large depreciation of their currency. Countries

\footnotetext{
${ }^{9}$ Textbook Mundell-Fleming theory is enough to deduce the signs of the capital controls and exchange rate regime dummies. See Aghion et. al. for theoretical explanation of the signs of the relationships with our dollarization measure.
} 
without controls would have to choose between low interest rates or little depreciation, but in principle cannot achieve both. For the exchange rate regime, ceteris paribus, the group of "fixers" should raise interest rates in response to a contractionary U.S. shock, since an interest rate differential with the U.S. would be inconsistent with a fixed exchange rate (and open capital markets, implicitly a part of our ceteris paribus assumption). The group of "floaters", on the other hand, could absorb part of the effect on the domestic interest rate by allowing their currency to depreciate against the U.S. dollar. Finally, countries with high degrees of dollarization or trade integration with the U.S. may behave as de facto fixers even if their official exchange rate regime is a float. Thus, one would expect the following signs in our regressions:

\begin{tabular}{|l|c|c|}
\hline & Exchange rate responses & Interest rate responses \\
\hline Capital Controls & - & - \\
\hline Exchange Regime & + & - \\
\hline Dollarization & - & + \\
\hline Trade integration & - & + \\
\hline
\end{tabular}

We need to account for uncertainty in the VAR and its effect on our second-stage regression estimates. To do so, we begin with the standard Runkle (1987) bootstrapping method to estimate confidence intervals around impulse responses. We generate one thousand artifical series from the actual data and reduced-form residuals, re-estimate the VAR, use the cumulative impulse responses to estimate our second stage regression a thousand times, and obtain the empirical distribution of the second stage coefficients. We report the second-stage coefficients from the original regression along with the 16.5 th and 83.5 th percentile of the empirical distribution. ${ }^{10}$

\section{$3 \quad$ Empirical Results}

\subsection{Panel Results}

Figure 2 displays the impulse responses of each variable to an identified U.S. monetary policy shock when the sample is divided between high and

\footnotetext{
${ }^{10}$ Thus, the reported band includes two-thirds of the estimates, or around plus or minus one standard deviation in a standard normal distribution, as in Leeper, Sims, and Zha (1996), Rogers (1999), and Faust and Rogers (2003). Note that this confidence band is "conservative", in the sense that it will lead us to find more evidence of a significant effect from capital controls, compared to using a wider plus-minus two standard deviations band. This makes our finding of essentially no significant effect of capital controls even stronger.
} 
low capital controls countries, along with their confidence bands. ${ }^{11}$ The responses of U.S. variables are familiar: a drop in NBRX and rise in the Fed Funds rate is accompanied a negative and hump-shaped response of U.S. industrial production (see Strongin (1995) and Faust and Rogers (2003) among many others). The price puzzle is present despite the inclusion of commodity prices. Foreign industrial production falls by less than in the United States.

Foreign interest rates rise and the currency depreciates against the U.S. dollar, but with some differences in magnitudes across groups. As noted above, if capital controls were binding one would expect both a lower interest rate response and smaller currency depreciation among the high controls group. In fact, Figure 2 does show on impact a significantly smaller depreciation for the group of high capital control countries, although the difference with the low controls group is not large. We also see that interest rates rise more in high capital control countries, a difference that is statistically significant at the peak response (around 6 months).

Examination of the individual country responses indicates that Mexico and Turkey (both in the high controls group) have unusually large, positive interest rate responses. To investigate whether the results are driven to any great extent by these potential outliers, we exclude Mexico and Turkey from the sample. The results, depicted in Figure 2-b, are very similar to those for the full sample.

In Figures 3 and 4 we compare interest rate and exchange rate responses, respectively, when the panel VARs are divided based on the other country factors. The top panel repeats the Figure 2 comparison based on capital controls. We exclude the responses of variables other than $\mathrm{S}$ and $\mathrm{R}^{*}$ for space consideration. However, these are virtually identical across groups and to those of Figure 2. The results go in the expected directions. The group of "fixers" raises interest rates by more than the countries with more flexible exchange rates (Fig. 3, row 2). The difference is significant at the peak. That difference is not trivial: peak interest rate responses are ten basis points higher for the fixers following a shock of twenty-five basis points. Also, the currencies of fixers depreciate by less on impact vis-a-vis

\footnotetext{
${ }^{11}$ Bootstrapping for the panel was done by generating initial conditions separately for each country as in Runkle (1997) but sampling from the entire panel vector of residuals. This was done to account for possible cross-country correlations. Drawing bands by sampling from each country separately leads to virtually identical results.
} 
the U.S. dollar (Fig. 4, row 2). This is in line with Broda (2002) who shows in a similar panel VAR setting that floating exchange rate regimes insulate countries from terms of trade shocks.

In highly dollarized countries and countries that have relatively high trade integration with the U.S., interest rates rise by more and currencies depreciate by less compared to their "low" counterparts, according to Figures 3 and 4 . In two of the four comparisons the differences are statistically significant. This is consistent with Haussman et al., who find - using very different techniques - that liability dollarization pushes countries to smooth exchange rate fluctuations.

To understand the apparently contradictory result that countries with high capital controls have both higher interest rate responses and lower exchange rate responses, note that subdividing countries by capital controls intensity leads to groupings similar to those obtained by dividing according to the other country factors (Table 1). The capital controls groupings might in fact be picking up exchange arrangement or dollarization effects. Thus we next estimate VARs country-by-country and perform "second-stage regressions" controlling for all country factors simultaneously.

\subsection{Bilateral results}

In Appendix 1 we display the impulse responses of all countries and all variables. To aid in ocular inference making, countries are depicted in ascending order of the capital controls index, that is, from the most open country (U.K.) to the most closed (Chile). ${ }^{12}$ Inspection of the individual country impulse responses suggests that our baseline VAR generally produces a reasonable representation of an identified U.S. monetary policy shock, by the standards of the literature. ${ }^{13}$

Tables $2 \mathrm{~A}$ and $2 \mathrm{~B}$ contain the results of our second-stage regressions. We present regressions with each country factor included separately, as well as one regression containing all four country factors together. We report the coefficients from the original impulse responses and the 16.5th and 83.5th

\footnotetext{
${ }^{12}$ The last five countries require a different scale and so are mixed.

${ }^{13}$ The responses of the U.S. variables are uniformly sensible, closely mirroring those of the panel VARs described above. Exceptions to the general pattern of "reasonable" responses include the occasional positive response of foreign output (e.g., the U.K. and Germany) and somewhat more pervasive price puzzle.
} 
percentiles of the bootstrap distributions. We present results at horizons of $6,12,24$, and 48 months.

The results are very consistent with the evidence from the panel regressions. Consider first the regressions explaining exchange rate responses (Table 2A). In the single-regressor estimates all variables are of the expected sign and statistically significant at the six-month horizon (upper left panel, first four columns). For example, the point estimate for the capital controls index is -1.49 , with a confidence band of -2.23 to -0.45 . The point estimate means that a twenty-five basis points contractionary shock in the U.S. induces a one hundred basis points larger depreciation in a relatively open country like Canada than in a more restrictive country like Korea, whose capital controls index is 0.65 higher than Canada's. The capital controls index is also negative and statistically significant at twelve months (upper right panel, first column), but insignificant at longer horizons (lower panels). According to the regression R-squared values, the capital controls index explains between six and twelve percent of the cross-sectional variation in exchange rate responses at the short horizons, but virtually none at longer horizons.

However, the (short-horizon) significance of the capital controls index vanishes when the other country factors are included. This can be seen from the final column of each panel, where the confidence band around the estimate for $\mathrm{KC}$ includes zero at all horizons considered. Due to the collinearity of capital controls and the other country factors, effects that might be attributed to capital restrictions are as likely to be a result of other country characteristics. In our case, the exchange rate regime dummy EA generally has larger effects than the capital controls index. The exchange rate regime is statistically significant at all horizons in the single-regressor estimates, has a reasonably high R-squared value, and retains significance up to the 24-month horizon when all regressors are included (final column of each panel). Finally, note that for all regressions, the R-squared decreases with the length of the horizon. This makes sense, as one would expect that most of the reaction in asset markets occurs soon after the shock.

Turning to interest rate responses (Table 2B), we see that the capital controls index is never statistically significant, consistent with the panel regressions. In contrast, our dollarization measure is significant and of the hypothesized sign in both individual and general regressions and at both short and long horizons. Countries with higher liability dollarization raise 
interest rates by more following a contractionary shock in the United States. The corresponding R-squared of fifteen to twenty percent at short-horizons is again relatively high. ${ }^{14}$

\subsection{Robustness}

The results so far suggest that the degree to which U.S. money shocks are transmitted to foreign interest rates and exchange rates is essentially unaffected by the barriers to capital flows imposed by the foreign economy. The impulse responses of the group of high capital controls countries are not very different from those of the low capital controls countries. Capital controls are found to be less important than the exchange rate regime or degree of liability dollarization as a factor determining the transmission of U.S. money shocks across countries. In this section we examine the robustness of these results to the choice of sample period, the use of an alternative measure of capital controls, the identification scheme adopted in the VAR, and the possible endogeneity of capital controls.

\subsubsection{Sample period}

To check whether the baseline results are robust to the choice of sample period, we re-estimate our panel VARs for the nine sub-periods containing at least two-thirds of the full sample, i.e., 1975-90, 1976-91, ..., 1983-1998. We ask, is there any sub-period for which the baseline VAR produces reasonable impulse responses and capital controls are found to be "effective"? Appendix 2 depicts the impulse responses for the high and low capital controls countries for each sub-period. ${ }^{15}$ In the first six sub-periods the impulse responses suggest that the monetary shock is reasonably identified (again with a pervasive price-puzzle). The interest rate responses $\mathrm{R}^{*}$ are uniformly larger in high capital control countries, although the differences are not always statistically significant. The more restricted countries experience a smaller depreciation of their currencies, as seen from the plots labeled S, but the difference is typically small and significant only at short horizons. This mirrors the results from the full sample period.

\footnotetext{
${ }^{14}$ Note the Tables $2 \mathrm{~A}$ and $2 \mathrm{~B}$ results exclude Mexico and Turkey. With Mexico and Turkey, capital controls are found to have the opposite effect as the one hypothesized: more stringent controls lead to larger interest rate responses.

${ }^{15}$ We keep the same country sub-divisions as in the full sample to maintain consistency.
} 
For the last three sub-periods - and in particular the last two (1982-97 and 1983-98) - the impulse responses do not suggest that a reasonable U.S. monetary policy shock has been identified: domestic and foreign output rise following a contractionary shock, non-borrowed reserves rise and then fall, and the price puzzle becomes very pronounced. However, even in these last three sub-periods our primary conclusions hold: if anything, interest rates responses in high controls countries become much larger. Further experimentation reveals that the "reasonableness" of the output, money, and price responses (though to repeat, not our conclusions concerning the effect of capital controls on the $\mathrm{R}^{*}$ and $\mathrm{S}$ responses) is sensitive to excluding the years 1979-81. In order to obtain more reasonable impulse responses for the sub-periods that include the last few years of the sample, therefore, we re-estimate the panel VARs for the periods 1980-96, 1980-97, and 198098. As can be seen from the Appendix, the impulse responses now suggest a more reasonable monetary policy shock, and once again our conclusions about the (in)effectiveness of capital controls is found to be robust.

\subsubsection{An alternative measure of capital controls}

We wish to make sure that our main fndings are not driven by the particular measure of capital account restrictions. The Miniane (2000) measure, despite being demonstrably preferable to the pre-1996 IFS index, is still imperfect both for being de jure and for not taking explicitly into account the severity of each individual restriction. In this section, we examine the robustness of our results to using an alternative measure of capital controls derived from the capital account openness measures of Lane and MilesiFerretti (2001). The Lane-Milesi-Ferretti (LMF) openness index is the ratio of the stock of portfolio and direct investment assets and liabilities to GDP. The measure is different from our baseline measure in that it is a de facto metric. It is also well-known. The disadvantage of LMF as a measure of capital account openness is that changes in asset prices can lead to changes in the measure even with no changes in underlying restrictions or in the underlying financial position. Values of the LMF index are displayed in Table 1. Note that the correlation between LMF and our baseline capital controls measure is negative $(-0.556)$, as it should be since the former measures capital account openness.

First, we use the LMF measure to separate our sample of countries between high and low capital controls groups and examine in our panel VAR setting whether interest rate and exchange rate responses are smaller for the 
former. ${ }^{16}$ As can be seen in Figure 5, the foreign interest rate responses $\mathrm{R}^{*}$ are insignificantly different in the two groups. The exchange rate depreciates by less in the high capital controls group, as seen in the panels labeled $\mathrm{S}$, but once again the difference is small and not persistent. These results are thus robust to using the alternative measure of capital account openness.

Second, in Tables 3A and 3B we present the country-by-country, "secondstage" regressions by analogy to Tables $2 \mathrm{~A}$ and $2 \mathrm{~B}$. For the exchange rate responses, the alternative measure is always insignificantly different from zero (Table 3A). For the interest rate responses, the KC-LMF measure of openness is positive and significant at the six-month horizon in both the single regressor and multiple regressor specifications. Its significance declines as the horizon increases, but KC-LMF is still positive and significant in the multiple regressor specifications up to 24 months. These results, which indicate that the interest rates of countries with de facto less open capital accounts (even if not more severe de jure more stringent capital account restrictions themselves) are less sensitive to U.S. monetary policy shocks, constitute the strongest evidence we have found of the "effectiveness" of restricted capital accounts. Note, however, that we have again excluded Mexico and Turkey to be consistent with the baseline estimates of Tables $2 \mathrm{~A}$ and $2 \mathrm{~B}$. Including Mexico and Turkey renders the KC-LMF coefficient in all $\mathrm{R}^{*}$ regressions insignificant, thus making even this evdence of capital controls effectiveness disappear. ${ }^{17}$

\subsubsection{Identification}

Recalling the controversies in the monetary VAR literature, it is important to test whether our results depend on the particular scheme used to identify the shocks. We re-estimate the "baseline" model using one hundred twenty different (recursive) identification schemes. In all cases, we fix CP, Y, and P at the top of the ordering, arguing that these variables do not react within a

\footnotetext{
${ }^{16}$ Of course, the grouping is somewhat different under the KC-LMF measure; otherwise this exercise would not be informative. The "low controls" group for our baseline measure KC is: Australia, Austria, Canada, Denmark, France, Germany, Italy, Japan, Netherlands, Norway, Portugal, and the UK; for KC-LMF it is: Austria, Belgium, Canada, Chile, France, Germany, Malaysia, Netherlands, Norway, Spain, Sweden, and the UK. Thus, 7 out of 12 countries overlap. The inclusion of Chile and Malaysia among the "low controls/high openness" countries in the LMF measure is arguably counter-intuitive, but is a by-product of the de facto nature of their measure.

${ }^{17}$ Recall that these countries have very closed capital accounts yet huge interest rate sensitivities to U.S. monetary shocks.
} 
month to foreign output, prices and asset market variables. We then allow all possible orderings among the remaining five variables in the system, yielding one hundred twenty specifications. Although this strategy falls short of the exhaustive search conducted in Faust and Rogers (2003), which is in principle over an infinite number of alternative schemes, it does represent a large set of plausible alternatives. Further, Faust, Rogers, Swanson, and Wright (2002) find that the baseline recursive structure we estimate in this paper cannot be rejected in favor of a large number of alternatives for one of the two currencies they examine.

Table 4 summarizes our results by showing the percentage of rotations in which the coefficient of interest is of the hypothesized sign and statistically significant at the $67 \%$ confidence level. The top row presents results for the exchange rate responses at various horizons, while the bottom row is for the interest rate responses. This robustness exercise largely confirms our original results. In the exchange rate equations, the capital controls index is only significant in one third of the rotations at the shortest horizon (top left panel), but this significance fully disappears when one includes the other regressors (top right panel). In contrast, the significance of the exchange rate regime appears very robust. This country factor is significant in more than half of the rotations at all horizons in single-regressor specifications, and in almost all of the rotations at all horizons in the joint estimation. For interest rate responses, capital controls are never significant at any horizon. The dollarization index is almost always significant, either alone or controlling for the other regressors. The new result emerging from this exercise is that the exchange rate regime also appears to be important for explaining interest rate responses, at least in the single-regressor estimates. In short, the exchange rate regime and dollarization seem to be the key variables explaining cross-sectional differences in responses, while the effect of capital controls is very weak at best.

\subsubsection{Endogeneity of capital controls}

It is possible that countries choose to restrict capital flows when vulnerable to foreign monetary disturbances. We would then observe in the data that high capital controls are associated with large interest rate and exchange responses. Even if capital controls "worked" in the sense that they subsequently insulated the inherently-vulnerable country from foreign disturbances, we might find in our regressions that capital controls are insignificant. 
To control for the possible endogeneity of our capital controls index, we instrument for it using Transparency International's well-known Corruption Perception Index. The index is an average of several survey-based measures of corruption from business executives, in-house experts at international consulting firms, and/or other people in the country in question. We use the average value of the corruption index from 1995 to 1999 (the index exists since 1995, measuring the year 1994). Values of the index are reported in Table 1. Note that a higher value corresponds to a less corrupt country. Time variation in the index is minimal: for our countries the correlation between the 1995 and 2002 values is 0.94 . This gives us some comfort that using the average value of the index from 1995-99 is not far different from what we would have computed if we had the data over our full sample period.

Two facts make the corruption index a good instrument for capital controls. First, the correlation between the corruption and capital controls measures is high, at -0.75 (Table 1). Countries with higher levels of corruption are likely to have more red tape and in particular heavier regulation of capital flows. This is consistent with Wei $(2000 \mathrm{a}, \mathrm{b})$, who uses the index to examine the effect of corruption on international investment. Second, there is good reason to believe on a priori grounds that corruption in a foreign country is not likely to be driven by U.S. monetary disturbances.

Tables 5A and 5B present the results of two-stage least squares estimation for the exchange rate and foreign interest rate responses, respectively, by analogy to the baseline results in Tables $2 \mathrm{~A}$ and $2 \mathrm{~B}$. Since the only country factor we instrument for is capital controls, we display only those specifications that include capital controls. The instrumented capital controls factor is, with one exception, insignificant at all horizons and in both single- and multiple-regressor specifications, while the exchange rate regime and the dollarization measures are significant and of the correct sign. The capital controls factor is negative and (barely) significant only for the $\mathrm{R}^{*}$ response at horizon six (Table 5b, upper left panel). This investigation in-

dicates that the possible endogeneity of capital controls does not appear to be spuriously driving our main findings.

\subsubsection{Exogeneity of U.S. variables}

In our bilateral VARs, U.S. variables can respond (with a lag) to foreign variables. Because of this, the response of U.S. output, prices, and money to a twenty five basis points Fed Funds rate shock can potentially vary across 
our country-specific VARs. Inspection of the impulse responses by country indicates that in fact they do vary, albeit not by much. To ensure uniformity of the U.S. responses across country VARs, we make CP, Y, P, FFR, and $\mathrm{M}$ block exogenous, and re-estimate the interest rate and exchange rate responses. ${ }^{18}$

It turns out that the responses of interest under the block exogeneity assumption are virtually no different than in the baseline case. The correlations of the new impulse responses with those obtained under the baseline specification are above 0.8 at all horizons, indicating that the U.S. block was not responding much to foreign variables in the first place. Tables $6 \mathrm{~A}$ and $6 \mathrm{~B}$ show the results from the new second-stage regressions. In this case, the finding that capital controls are ineffective is even stronger than in our baseline estimates, as the index is not significantly negative in any specification at any horizon. The exchange rate regime and the degree of dollarization factors are significant and of the hypothesized sign once again, while the trade integration measure becomes more significant in the interest rate regression.

\section{Conclusion}

In posing the provocative question "Who needs capital account convertibility?", Rodrik (1998) argues that if countries' investment and output growth rates are not inhibited by capital controls, as he finds, the potential costs associated with capital account openness far exceed the benefits. Eichengreen's (2002) survey concludes that capital controls may or may not affect investment and output growth across countries, and points to the difficulty of teasing such effects out of the data. In this paper, we pursue an implication of capital controls that is more direct and arguably more easily tested: controls ought to insulate asset markets from foreign disturbances. To adopt Rodrik's line of reasoning from the other end, since there are costs, at least administrative ones, to imposing capital controls, it is also good to know whether controls are insulating home asset markets as they should.

Our particular strategy is to test whether or not high capital controls countries exhibit smaller responses of their interest rates and exchange rates

\footnotetext{
${ }^{18}$ We do not assume U.S. block exogeneity in our benchmark estimations to allow for easier replication of our results. Note also that inspection of the impulse responses under block exogeneity (not displayed) indicates that the responses of U.S. variables were indeed identical across countries once the VAR was restricted.
} 
to U.S. monetary shocks. Looking systematically at a large range of country experiences in a uniform estimation framework, we find essentially no evidence that capital controls are effective in this sense. Countries with more stringent controls apparently do experience smaller currency depreciations, but this result holds only at short horizons (as one would expect) and only if we do not condition on other relevant country factors like the degree of dollarization or the type of exchange rate arrangement. We also find that countries with more stringent capital controls do not experience smaller interest rate increases in response to contractionary U.S. monetary shocks. These findings are highly robust to the choice of sample period, the identification scheme adopted in the VAR, and the possible endogeneity of capital account restrictions. The results are also largely robust to an alternative, de facto proxy for capital controls.

Why might capital controls have little or no effect? One reason is that controls are hard to enforce and can be evaded at small cost. If the opportunity cost of not evading controls - missing higher returns abroad - is high, agents will take their chances. Our measure of capital controls does not give any indication whether the government is making an effort to enforce them. Unfortunately, there is no systematic source of information regarding enforcement. Note that our results come from regressing average responses on the average level of capital controls, where averages are taken over periods relatively long periods of sixteen years or more. It is possible that controls are effective for a brief time after being established and are then left in place by bureaucratic inertia. In this case, the short-lived effect may not be picked up by our averaging. Nonetheless, note that important effects coming from the exchange rate regime and the degree of dollarization are detected despite our averaging.

\section{Bibliography}

- Aghion, P., Bachetta, P., and A. Banerjee, "Currency Crises and Monetary Policy in an Economy with Credit Constraints," mimeo, UCL, 2000 .

- Ariyoshi, A. et al., "Capital Controls: Country Experiences with Their Use and Liberalization", IMF Occasional Paper 190, May 2000.

- Broda, C., "Terms of Trade and Exchange Rate Regimes in Developing Countries", Federal Reserve Bank of New York Staff Report 148, March 2002, Journal of International Economics, forthcoming. 
- Cardoso, J., and B. Laurens, "Managing Capital Flows: Lessons From the Experience of Chile," IMF Working Paper 98/168, 1998.

- Clarida, R., and J. Gali, "Sources of Real Exchange Rate Fluctuations: How Important Are Nominal Shocks?," Carnegie-Rochester Conference Series on Public Policy, vol. 41, 1994, pp. 1-56.

- Chinn, M. D., and H. Ito, 2002, "Capital Account Liberalization, Institutions, and Financial Development," NBER Working Paper 8967.

- De Gregorio, J., Edwards, S., and R. Valdés, "Controls on Capital Inflows: Do They Work?," Journal of Development Economics, vol.63, October 2000, pp. 59-83.

- Desai, M. A., Foley, C. F., and J. R. Hines Jr., 2003, "Capital Controls, Liberalizations, and Foreign Direct Investment," available at http://wpweb2k.gsia.cmu.edu/wfa/wfapdf/dfhcapcontapr03.pdf.

- Dooley, M. P., "A Survey of Literature on Controls Over International Capital Transactions," IMF Staff Papers, vol. 43, December 1996, pp. 639-87.

- Edison, H., and C. M. Reinhart, "Stopping Hot Money," Journal of Development Economics, vol. 66, December 2001, pp. 533-553.

- Edwards, S., 2001, "Capital Mobility and Economic Performance: Are Emerging Economies Different?" NBER Working Paper 8076.

- Eichenbaum, M., and C. L. Evans, "Some Empirical Evidence on the Effects of Shocks to Monetary Policy on Exchange Rates," Quarterly Journal of Economics, vol. 110, November 1995, pp. 975-1009.

- Eichengreen, B., 2002, "Capital Account Liberalization: What do the Cross-Country Studies Tell Us?" World Bank Economic Review.

- Faust, J., "The Robustness of VAR Conclusions About Money," CarnegieRochester Conference on Public Policy, vol. 49, December 1998, pp. 207-244.

- Faust, J., and J. H. Rogers, "Monetary Policy's Role in Exchange Rate Behavior," Journal of Monetary Economics, forthcoming October 2003. 
- Faust, J., Rogers, J.H., Swanson, E., Wright, J.H., "Identifying the Effects of Monetary Policy Shocks on Exchange Rates Using High Frequency Data," Journal of the European Economic Association, forthcoming.

- Fieleke, N. S., "International Capital Transactions: Should They Be Restricted?", New England Economic Review, Federal Reserve Bank of Boston, March-April 1994, pp. 27-39.

- Grilli, V., and G. M. Milesi-Ferretti, "Economic Effects and Structural Determinants of Capital Controls," IMF Staff Papers, vol. 42, September 1995, pp. 517-51.

- Gros, D., "The Effectiveness of Capital Controls: Implications for Monetary Autonomy in the Presence of Incomplete Market Separation," IMF Staff Papers, vol. 34, December 1987, pp. 621-642.

- Gros, D., "Dual Exchange Rates in the Presence of Incomplete Market Separation: Long-Run Effectiveness and Policy Implications," IMF Staff Papers, vol. 35, September 1988, pp. 437-460.

- Hausmann, R., Panizza, U., and E. Stein, "Why Do Countries Float the Way They Float?", Journal of Development Economics, vol. 66, December 2001, pp. 387-414.

- Kaplan, E., and D. Rodrik, "Did the Malaysian Capital Controls Work?", NBER Working Paper 8142, February 2001.

- Kim, S., and N. Roubini (2000): Exchange Rate Anomalies in the Industrial Countries: a Solution with a Structural VAR Approach, Journal of Monetary Economics, 45, 561-586.

- Lane, P., and G.M. Milesi-Ferretti, "The External Wealth of Nations: Measures of Foreign Assets and Liabilities for Industrial and Developing Countries," Journal of International Economics, vol. 55, 2001, pp. 263-294.

- Leeper, E., Sims, C., and T. Zha, "What Does Monetary Policy Do?," Brookings Papers on Economic Activity, 2:1996, pp. 341-369.

- Miniane, J., "A New Set of Measures on Capital Account Restrictions," unpublished draft, Johns Hopkins University, October 2000. 
- Reinhart, C., and K. S. Rogoff, "The Modern History of Exchange Rate Arrangements: A Reinterpretation," NBER Working Paper 8963, May 2002.

- Rodrik, D, 1998, "Who Needs Capital Account Convertibility?" Princeton Essays in International Finance, 207, pp. 55-65.

- Rogers, J., "Monetary Shocks and Real Exchange Rates," Journal of International Economics, vol. 48, 1999, pp. 269-288.

- Runkle, D. E., "Vector Autoregressions and Reality," Journal of Business and Economic Statistics, vol. 5, 1987, pp. 437-442.

- Quinn, D. P., 1997. "The Correlates of Changes in International Financial Regualtion," American Political Science Review, 91, pp. 531551.

- Strongin, S., "The Identification of Monetary Policy Disturbances: Explaining the Liquidity Puzzle," Journal of Monetary Economics, vol. 35, 1995, pp. 463-498.

- Wei, S. J., "How Taxing is Corruption on Local Investors?", Review of Economics and Statistics, vol. 82, February 2000a, pp. 1-11.

- Wei, S. J., "Local Corruption and Global Capital Flows," Brookings Papers on Economic Activity, 2000b, pp. 303-354.

\section{Data appendix}

All VAR data are monthly, spanning the period January 1975 - December 1998 unless indicated. Non-seasonally adjusted data were adjusted using the Fed's X-11 routine. For foreign interest rates, we tried to obtain the closest available equivalent to the U.S. 3-month Tbill. Note that FRBI stands for Federal Reserve Board International Database, FRBD for its counterpart domestic database, and IFS for International Financial Statistics.

- Nominal Exchange Rates: IFS, all countries.

- Industrial Production Index: (1) IFS for Austria, Canada, Colombia, France, Germany, Greece, India, Italy, Japan, Korea, Malaysia, Mexico, Netherlands, Norway, Philipines, South Africa, Spain, Sweden, UK; (2) Turkish central bank for Turkey; (3) FRBI for Australia, 
Belgium, Chile, Denmark, Finland, Portugal; and (4) FRBD for the U.S.

- Consumer Price Index: IFS for all countries except Australia (FRBI) and U.S. (FRBD).

- Commodity Price: Producer Price Index - All Commodities, FREDSaint Louis.

- Federal Funds Rate: FRED-Saint Louis.

- U.S. Non-borrowed Reserves and Total Reserves: FRBD.

- Interest Rates: Australia: 13-week T-bill Rate, IFS; Austria: Money Market Rate, IFS; Belgium: Call Money Rate, IFS; Canada: T-bill Rate, IFS; Chile: Lending Rate, IFS; Colombia: Discount Rate, IFS; Denmark: Call-Money Rate, IFS; Finland: Lending Rate, IFS; France: T-bill Rate, IFS; Germany: Call Money Rate, IFS; Greece: Central Bank Rate, IFS; India: Call Money Rate, IFS; Italy: T-bill Rate, IFS; Japan: Call Money Rate, IFS; Korea: Money Market Rate, IFS; Malaysia: T-bill Rate, IFS; Mexico: T-bill Rate, IFS; Netherlands: Money Market Rate, IFS; Norway: Call Money Rate, IFS; Philippines: T-bill Rate, IFS; Portugal: T-bill Rate, Eurostat; South Africa: T-bill Rate, IFS; Spain: Money Market Rate, IFS; Sweden: Money Market Rate, IFS; Turkey: 3-month Deposit Rate, Central Bank of the Republic of Turkey; UK: T-bill Rate, IFS.

- United States: Industrial Production Index from FRBD, Consumer Price Index from FRBD, Producer Price Index - All Commodities from FRED-Saint Louis, Federal Funds Rate from FRED-Saint Louis, Non-borrowed Reserves and Total Reserves from FRBD.

Data on exchange rate regimes was obtained from the Exchange Arrangements and Exchange Restrictions publication of the International Monetary Fund. Trade integration data starts in 1980 and was taken from the Direction of Trade Statistics of the IMF. International banking claims data starts in 1990 and comes from the Bank of International Settlements. Capital Controls data starts in 1983 and was taken from Miniane (2000). The Lane and Milesi-Ferretti measure was kindly provided by the authors. The Transparency International Corruption Perceptions Index can be found at www.transparency.org 
Table1: Country Factors

\begin{tabular}{|c|c|c|c|c|c|c|c|c|}
\hline Country & $\mathrm{KC}$ & KC-IFS & KC-LMF & EA-IFS & EA-RR & USTR & DOL & CORRUP \\
\hline Australia & 0.492 & 0.077 & 0.6 & 3.594 & 2.979 & 0.041 & 0.454 & 8.732 \\
\hline Austria & 0.481 & 0.615 & 1.779 & 4 & 4 & 0.016 & 0.185 & 7.486 \\
\hline Belgium & 0.553 & 0 & 3.506 & 4 & 4 & 0.127 & 0.295 & 5.928 \\
\hline Canada & 0.192 & 0 & 2.306 & 4 & 3 & 0.388 & 0.550 & 9.066 \\
\hline Chile & 1 & 1 & 0.872 & 1.976 & 2.969 & 0.092 & 0.838 & 6.898 \\
\hline Colombia & 0.970 & 1 & 0.618 & 2.313 & 2.635 & 0.112 & 0.861 & 2.7 \\
\hline Denmark & 0.269 & 0.385 & 0.773 & 4 & 4 & 0.024 & 0.225 & 9.718 \\
\hline Finland & 0.558 & 0.615 & 0.732 & 2.861 & 4.024 & 0.027 & 0.275 & 9.41 \\
\hline France & 0.462 & 0.538 & 1.065 & 4 & 4 & 0.023 & 0.271 & 6.784 \\
\hline Germany & 0.231 & 0 & 0.888 & 4 & 4 & 0.030 & 0.121 & 8.108 \\
\hline Greece & 0.548 & 1 & 0.461 & 2.882 & 3.326 & 0.015 & 0.438 & 4.84 \\
\hline India & 0.917 & 1 & 0.082 & 2.549 & 2.191 & 0.021 & 0.556 & 2.792 \\
\hline Italy & 0.428 & 0.538 & 0.471 & 4 & 3.660 & 0.022 & 0.185 & 4.148 \\
\hline Japan & 0.471 & 0.077 & 0.423 & 4 & 3.878 & 0.044 & 0.518 & 6.428 \\
\hline Korea & 0.841 & 1 & 0.247 & 1.875 & 1.899 & 0.122 & 0.795 & 4.32 \\
\hline Malaysia & 0.846 & 0 & 1.614 & 2.191 & 3.028 & 0.222 & 0.535 & 5.202 \\
\hline Mexico & 0.882 & 1 & 0.705 & 2.441 & 2.892 & 0.262 & 0.842 & 3.168 \\
\hline The Netherlands & 0.149 & 0 & 4.806 & 4 & 4 & 0.063 & 0.325 & 8.886 \\
\hline Norway & 0.409 & 0.923 & 0.848 & 3.014 & 3.538 & 0.044 & 0.533 & 8.86 \\
\hline The Philippines & 0.894 & 1 & 0.395 & 2.250 & 2.667 & 0.149 & 0.757 & 3.082 \\
\hline Portugal & 0.495 & 0.769 & 0.625 & 2.861 & 4 & 0.025 & 0.263 & 6.452 \\
\hline South Africa & 0.861 & 1 & 0.555 & 3.531 & 3.160 & 0.051 & 0.669 & 5.29 \\
\hline Spain & 0.603 & 0.846 & 0.885 & 4 & 3.500 & 0.018 & 0.269 & 5.452 \\
\hline Sweden & 0.519 & 0.769 & 1.619 & 2.861 & 3.747 & 0.039 & 0.328 & 9.24 \\
\hline Turkey & 0.773 & 1 & 0.135 & 3.375 & 4.566 & 0.020 & 0.541 & 3.57 \\
\hline U.K. & 0.077 & 0 & 3.585 & 4 & 3.080 & 0.050 & 0.344 & 8.506 \\
\hline Mean & 0.574 & 0.583 & 1.177 & 3.253 & 3.413 & 0.079 & 0.460 & 6.349 \\
\hline Standard deviation & 0.269 & 0.420 & 1.167 & 0.767 & 0.652 & 0.090 & 0.226 & 2.311 \\
\hline
\end{tabular}

\section{Country Factors: Sample Correlations}

$\begin{array}{ccccccccc}\text { KC } & \text { KC } & \text { KC-IFS } & \text { KC-LMF } & \text { EA-IFS } & \text { EA-RR } & \text { USTR } & \text { DOL } & \text { CORRUP } \\ \text { KC-IFS } & 1 & & & & & & & \\ \text { KC-LMF } & 0.692 & 1 & & & & & & \\ \text { EA-IFS } & -0.556 & -0.632 & 1 & & & & \\ \text { EA-RR } & -0.776 & -0.606 & 0.419 & 1 & & & \\ \text { USTR } & 0.139 & -0.307 & 0.227 & 0.625 & 1 & & & \\ \text { DOL } & 0.735 & 0.498 & -0.205 & -0.244 & -0.417 & 1 & & \\ \text { CORRUP } & -0.749 & -0.556 & 0.452 & -0.726 & -0.710 & 0.492 & 1 & \\ \end{array}$

Note: KC stands for Miniane's (2000) capital controls index, KC-IFS for the IMF's pre-1996 zero/one capital controls dummy, KC-LMF for Lane and Milesi-Ferretti's (2001) capital controls measure, EA-IFS for the IMF's exchange rate classification, EA-RR for Reinhart and Rogoff's (2002) exchange rate classification, USTR for the ratio of exports to the U.S. plus imports from the U.S. as a share of the country's GDP, DOL for the share of the country's foreign currency banking sector claims that are in U.S. dollars, and CORRUP for Transparency International's corruption perception index. All variables are expressed as the country's sample period average, given data availability constraints (see text). A higher value for the $\mathrm{KC}$-LMF measure corresponds to a more open capital account, thus explaining the negative correlation between $\mathrm{KC}$ and $\mathrm{KC}-\mathrm{LMF}$. 


\section{Table 2a: Regressions for Exchange Rate Responses at Various Horizons \\ Table 2a: Regressions for Exchange Rate Responses at Various Horizons}

Six-Month Cumulative ER Response

\begin{tabular}{|c|c|c|c|c|c|c|c|c|c|c|c|}
\hline \multirow[b]{2}{*}{ Constant } & \multicolumn{5}{|c|}{ Six-Month Cumulative ER Response } & \multicolumn{6}{|c|}{ Twelve-Month Cumulative ER Response } \\
\hline & 1.5707 & -1.5455 & 1.0179 & 1.7739 & -0.9696 & Constant & 1.8636 & -3.6519 & 0.7868 & 1.6739 & -5.6991 \\
\hline & $(0.812 .04)$ & $(-2.40-0.50)$ & $(0.611 .22)$ & $(1.052 .23)$ & $(-3.060 .78)$ & & $(0.433 .24)$ & $(-5.90-1.20)$ & $(-0.031 .41)$ & $(0.293 .00)$ & $(-9.78-0.53)$ \\
\hline \multirow[t]{2}{*}{ Kc } & -1.4863 & & & & 0.429 & KC & -2.4476 & & & & 0.3099 \\
\hline & $(-2.23-0.45)$ & & & & $(-0.781 .81)$ & & $(-4.56-0.27)$ & & & & $(-2.723 .26)$ \\
\hline \multirow[t]{2}{*}{ EA } & & 0.6993 & & & 0.6074 & EA & & 1.2685 & & & 1.6642 \\
\hline & & $(0.350 .96)$ & & & $(0.201 .01)$ & & & $(0.511 .95)$ & & & $(0.592 .48)$ \\
\hline \multirow[t]{2}{*}{ USTR } & & & -3.6491 & & -1.8379 & USTR & & & -3.7488 & & -3.2168 \\
\hline & & & $(-5.14-1.49)$ & & $(-3.670 .51)$ & & & & $(-8.240 .67)$ & & $(-8.132 .42)$ \\
\hline \multirow[t]{2}{*}{ DOL } & & & & -2.3226 & -0.853 & DOL & & & & -2.6365 & 1.8454 \\
\hline & & & & $(-3.23-1.05)$ & $(-2.240 .58)$ & & & & & $(-5.370 .01)$ & $(-2.184 .89)$ \\
\hline \multirow[t]{2}{*}{ R-squared } & 0.1176 & 0.2201 & 0.0707 & 0.1932 & 0.2638 & R-squared & 0.0537 & 0.122 & 0.0126 & 0.0419 & 0.1347 \\
\hline & Twenty $\mathrm{F}$ & Four-Mont & th Cumula & ative ER Re & Response & & \multicolumn{5}{|c|}{ Forty Eight-Month Cumulative ER Response } \\
\hline \multirow[t]{2}{*}{ Constant } & 1.5805 & -8.0206 & 0.0295 & 1.0758 & -15.9727 & Constant & 1.6668 & -11.2581 & -0.0707 & 1.9617 & -18.8136 \\
\hline & $(-0.644 .80)$ & $(-12.07-1.55)$ & $(-0.911 .88)$ & $(-0.984 .56)$ & $(-20.40-1.45)$ & & $(-0.617 .83)$ & $(-18.500 .60)$ & $(-0.673 .44)$ & $(-0.348 .66)$ & $(-21.709 .01)$ \\
\hline \multirow[t]{2}{*}{ KC } & -3.6746 & & & & 1.5456 & KC & -4.9211 & & & & 3.8105 \\
\hline & $(-8.370 .68)$ & & & & $(-5.206 .87)$ & & $(-13.721 .74)$ & & & & $(-8.159 .46)$ \\
\hline \multirow[t]{2}{*}{ EA } & & 2.3068 & & & 3.8164 & EA & & 3.1098 & & & 4.5773 \\
\hline & & $(0.583 .60)$ & & & $(0.784 .81)$ & & & $(0.165 .64)$ & & & $(-0.905 .64)$ \\
\hline \multirow[t]{2}{*}{ USTR } & & & -6.5169 & & -7.569 & USTR & & & -13.3382 & & -10.4263 \\
\hline & & & $(-17.121 .89)$ & & $(-17.284 .19)$ & & & & $(-30.340 .50)$ & & $(-25.688 .31)$ \\
\hline \multirow[t]{2}{*}{ DOL } & & & & -3.4595 & 6.123 & DOL & & & & -6.8333 & 3.1765 \\
\hline & & & & $(-9.981 .34)$ & $(-4.18$ 10.45) & & & & & $(-18.861 .73)$ & $(-14.34$ 10.19) \\
\hline R-squared & 0.0248 & 0.0827 & 0.0078 & 0.0148 & 0.1093 & R-squared & 0.015 & 0.0507 & 0.011 & 0.0195 & 0.0626 \\
\hline
\end{tabular}

Twelve-Month Cumulative ER Response

Note 1: Results exclude Mexico and Turkey

Note 2: In parenthesis are the 16.5th and 83.5th percentiles of the coefficient's distribution

Note 3: The R-squared are computed from the regression using the original impulse responses 


\section{Table 2b: Regressions for Foreign Interest Rate Responses at Various Horizons}

Six-Month Cumulative $\mathbf{R}^{*}$ Response

\begin{tabular}{|c|c|c|c|c|c|c|c|c|c|c|c|}
\hline \multirow[t]{2}{*}{ Constant } & -0.0044 & 0.6854 & 0.1611 & -0.1427 & -0.2753 & Constant & 0.0934 & 1.5419 & 0.4442 & -0.2377 & -0.3514 \\
\hline & $(-0.200 .18)$ & $(0.051 .25)$ & $\left(\begin{array}{lll}0.08 & 0.23\end{array}\right)$ & $(-0.350 .06)$ & $(-0.810 .19)$ & & $(-0.290 .46)$ & $(0.212 .49)$ & $(0.240 .55)$ & $(-0.590 .19)$ & $(-1.440 .68)$ \\
\hline \multirow[t]{2}{*}{ KC } & 0.41 & & & & -0.1383 & KC & 0.8229 & & & & -0.5648 \\
\hline & $(-0.080 .86)$ & & & & $(-0.490 .21)$ & & $(-0.141 .63)$ & & & & $\left(\begin{array}{lll}-1.17 & 0.29)\end{array}\right.$ \\
\hline \multirow[t]{2}{*}{ EA } & & -0.1412 & & & 0.0355 & EA & & -0.3028 & & & 0.0479 \\
\hline & & $(-0.300 .03)$ & & & $(-0.070 .15)$ & & & $(-0.570 .04)$ & & & $(-0.180 .28)$ \\
\hline \multirow[t]{2}{*}{ USTR } & & & 0.829 & & -0.2813 & USTR & & & 1.4129 & & -1.2604 \\
\hline & & & $(0.24 \quad 1.39)$ & & $\left(\begin{array}{lll}-0.88 & 0.32\end{array}\right)$ & & & & $(-0.042 .67)$ & & $(-2.530 .31)$ \\
\hline \multirow[t]{2}{*}{ DOL } & & & & 0.827 & 1.0836 & DOL & & & & 1.7813 & 2.601 \\
\hline & & & & $(0.201 .42)$ & $(0.531 .65)$ & & & & & $(0.412 .75)$ & (1.24 3.33) \\
\hline \multirow[t]{2}{*}{ R-squared } & 0.055 & 0.0551 & 0.0224 & 0.1505 & 0.1572 & R-squared & 0.065 & 0.0744 & 0.0191 & 0.2049 & 0.2258 \\
\hline & \multicolumn{5}{|c|}{ Twenty Four-Month Cumulative $R^{*}$ Response } & & \multicolumn{5}{|c|}{ Forty Eight-Month Cumulative $\mathbf{R}^{*}$ Response } \\
\hline \multirow[t]{2}{*}{ Constant } & 0.1251 & 2.7521 & 0.9556 & -0.1145 & 0.3954 & Constant & 0.1703 & 3.7576 & 1.3687 & 0.2416 & 2.9258 \\
\hline & $(-0.420 .76)$ & $(0.063 .62)$ & $(0.471 .00)$ & $(-0.560 .66)$ & $(-1.712 .30)$ & & $(-0.650 .96)$ & $(-0.134 .55)$ & $(0.451 .23)$ & $(-0.601 .04)$ & $(-1.284 .72)$ \\
\hline \multirow[t]{2}{*}{ KC } & 1.519 & & & & -0.4979 & KC & 1.917 & & & & -0.4342 \\
\hline & $(-0.352 .34)$ & & & & $(-1.471 .12)$ & & $(-0.672 .83)$ & & & & $(-2.041 .69)$ \\
\hline \multirow[t]{2}{*}{ EA } & & -0.5447 & & & -0.0957 & EA & & -0.7703 & & & -0.5916 \\
\hline & & $(-0.830 .13)$ & & & $(-0.480 .37)$ & & & $(-1.040 .18)$ & & & $(-0.970 .28)$ \\
\hline \multirow[t]{2}{*}{ USTR } & & & 0.1233 & & -3.4567 & USTR & & & -1.884 & & -4.8335 \\
\hline & & & $(-3.052 .50)$ & & $\left(\begin{array}{lll}-5.26 & 0.23)\end{array}\right.$ & & & & $\left(\begin{array}{lll}-4.98 & 2.58)\end{array}\right.$ & & $\left(\begin{array}{lll}-6.57 & 1.09\end{array}\right)$ \\
\hline \multirow[t]{2}{*}{ DOL } & & & & 2.4458 & 3.2026 & DOL & & & & 2.2399 & 1.9074 \\
\hline & & & & $(-0.333 .31)$ & $(0.183 .68)$ & & & & & $(-1.013 .49)$ & $(-1.293 .57)$ \\
\hline R-squared & 0.0887 & 0.0964 & 0.0001 & 0.1547 & 0.1888 & R-squared & 0.124 & 0.1693 & 0.0119 & 0.1139 & 0.2296 \\
\hline
\end{tabular}

Notes: see notes in Table $2 a$. 


\section{Table 3a: Robustness to Alternative Measures of Controls (Exchange Rate Responses)}

Six-Month Cumulative ER Response

Constant

$$
0.594
$$$$
(0.230 .89)
$$

KC-LMF

$$
0.1251
$$

$(-0.050 .28)$

$(-0.250 .2)$

EA

USTR

DOL

R-squared

0.016

0.262

$(-2.160 .84)$

0.549

(0.13 0.93)

$-1.9677$

$(-3.57-0.14)$

$-0.6487$

$(-1.910 .8)$
Twenty Four-Month Cumulative ER Response

Constant

$$
-1.0207
$$

$(-2.231 .1)$

0.4598

$(-0.311 .23)$

EA

USTR

DOL

R-squared

0.0077
Constant

Twelve-Month Cumulative ER Response

$\begin{array}{cc}0.2662 & -5.4623 \\ (-0.591 .09) & (-8.75-1.56) \\ & \\ 0.1971 & -0.1204 \\ (-0.170 .59) & (-0.620 .39)\end{array}$

EA

1.6748

(0.65 2.51)

USTR

$-2.7538$

(-7.03 1.75)

DOL

1.8798

R-squared

0.0068

0.1362

Forty Eight-Month Cumulative ER Response

Constant

$-1.9274$

$-15.2606$

(-3.27 2.04)

(-18.31 6.31)

KC-LMF

0.705

0.1679

$(-0.451 .85)$

$(-1.131 .69)$

EA

3.8438

$(-0.795 .13)$

USTR

$-13.8471$

(-28.01 5.88)

DOL

5.4524

$(-12.79$ 10.9)

R-squared

0.06

Notes: see notes in Table $2 a$. 
Table 3b: Robustness to Alternative Measures of Controls (Foreign Interest Rate Responses)

Six-Month Cumulative $\mathbf{R}^{*}$ Response

\begin{tabular}{|c|c|c|}
\hline \multirow[t]{2}{*}{ Constant } & 0.1414 & -0.343 \\
\hline & $(0.020 .25)$ & $(-0.75-0.01)$ \\
\hline \multirow[t]{2}{*}{ KC-LMF } & 0.0651 & 0.1508 \\
\hline & $\left(\begin{array}{l}0.02 \\
0.11)\end{array}\right.$ & $\left(\begin{array}{lll}0.08 & 0.2\end{array}\right)$ \\
\hline \multirow[t]{2}{*}{ EA } & & -0.0201 \\
\hline & & $(-0.120 .1)$ \\
\hline \multirow[t]{2}{*}{ USTR } & & -1.0246 \\
\hline & & $(-1.86-0.16)$ \\
\hline \multirow[t]{2}{*}{ DOL } & & 1.1774 \\
\hline & & $(0.571 .76)$ \\
\hline \multirow[t]{2}{*}{ R-squared } & 0.0273 & 0.2576 \\
\hline & \multicolumn{2}{|c|}{ Twenty Four-Month Cumulative $R^{*}$ Response } \\
\hline \multirow[t]{2}{*}{ Constant } & 0.8565 & 0.107 \\
\hline & $(0.221 .05)$ & $(-1.231 .68)$ \\
\hline \multirow[t]{2}{*}{ KC-LMF } & 0.0873 & 0.4295 \\
\hline & $(-0.120 .24)$ & $(0.080 .46)$ \\
\hline \multirow[t]{2}{*}{ EA } & & -0.2362 \\
\hline & & $(-0.530 .22)$ \\
\hline \multirow[t]{2}{*}{ USTR } & & -5.5049 \\
\hline & & $(-6.99-0.68)$ \\
\hline \multirow[t]{2}{*}{ DOL } & & 3.4126 \\
\hline & & $(0.284 .09)$ \\
\hline R-squared & 0.0058 & 0.2834 \\
\hline
\end{tabular}

Twelve-Month Cumulative $R^{\star}$ Response

Constant

$$
0.4094
$$

$-0.7518$

$(0.130 .6)$

$(-1.560 .07)$

KC-LMF

0.112

0.299

$(-0.020 .19)$

$(0.130 .37)$

EA

$-0.013$

$(-0.220 .24)$

USTR

$-2.5436$

$(-4.02-0.39)$

DOL

2.6277

(1.11 3.54)

R-squared

0.0237

0.3344

Forty Eight-Month Cumulative $\mathbf{R}^{*}$ Response

Constant

1.3495

2.6485

(0.26 1.49)

$(-0.663 .63)$

KC-LMF

$-0.0965$

0.3081

$(-0.360 .18)$

$(-0.160 .39)$

EA

$-0.6794$

$(-0.880 .18)$

USTR

$-6.2521$

$(-7.520 .95)$

DOL

2.0158

$(-1.463 .51)$

R-squared

0.0062

0.2717

Notes: see notes in Table $2 a$. 


\section{Table 4: Robustness to Identification}

Single Regressor Estimation

$\begin{array}{lcccc} & \mathbf{S 6} & \mathbf{S 1 2} & \mathbf{S 2 4} & \mathbf{S 4 8} \\ \text { KC } & 33.33 & 9.17 & 0 & 0 \\ \text { EA } & 50 & 74.17 & 65 & 52.5 \\ \text { USTR } & 35.83 & 0 & 0 & 7.5 \\ \text { DOL } & 35 & 0.83 & 0 & 0\end{array}$

Single Regressor Estimation

$\begin{array}{lcccc} & \text { RF6 } & \text { RF12 } & \text { RF24 } & \text { RF48 } \\ \text { KC } & 0 & 0 & 0 & 0 \\ \text { EA } & 86.67 & 65.83 & 49.17 & 23.33 \\ \text { USTR } & 100 & 91.67 & 50 & 50 \\ \text { DOL } & 100 & 100 & 89.17 & 59.17\end{array}$

Joint Regressors Estimation

$\begin{array}{cccc}\mathbf{S 6} & \mathbf{S 1 2} & \mathbf{S 2 4} & \mathbf{S 4 8} \\ 0 & 0 & 0 & 0 \\ 95.83 & 100 & 100 & 73.33 \\ 0 & 0 & 0 & 0.83 \\ 0 & 0 & 0 & 0\end{array}$

Joint Regressors Estimation

$\begin{array}{cccc}\text { RF6 } & \text { RF12 } & \text { RF24 } & \text { RF48 } \\ 0 & 0 & 0 & 0 \\ 0 & 0 & 0 & 0 \\ 31.67 & 31.67 & 29.17 & 49.17 \\ 100 & 100 & 94.17 & 55\end{array}$

Notes: Figures correspond to the percentage of rotations in which the coefficient is significant (and of the right sign) at $67 \%$ confidence in the boostrapping distribution. S6 stands for the six-month exchange rate response. 


\section{Table 5a: Instrumental Variables Regressions for Exchange Rate Responses}

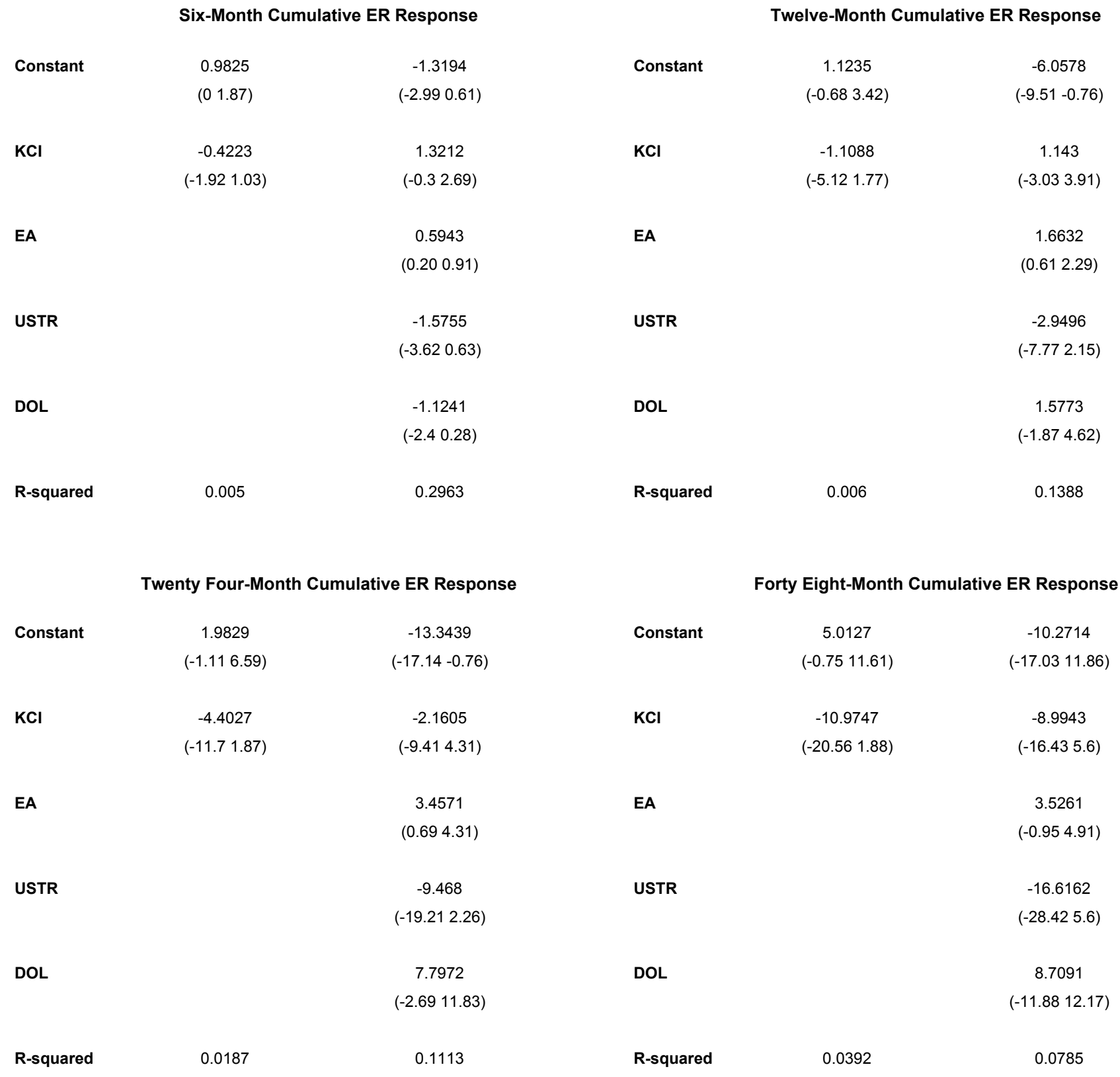

Notes: see notes in Table 2a. The estimates of $\mathrm{KCl}$ come from a $2 \mathrm{SLS}$ regression in which the Miniane capital controls measures are instrumented for with the period average of the Transparency International's Corruption Perception Index, whose values are listed in Table 1. 


\section{Table 5b: Instrumental Variables Regressions for Foreign Interest Rate Responses}

Six-Month Cumulative $\mathbf{R}^{\star}$ Response

Constant

$$
0.2795
$$

(0.02 0.5)

$\mathrm{KCl}$

$$
-0.1038
$$$$
(-0.480 .35)
$$

EA

USTR

DOL

R-squared

0.0018

Twenty Four-Month Cumulative $\mathbf{R}^{*}$ Response

Constant

$$
0.7659
$$$$
(-0.391 .33)
$$

0.3597

$(-1.292 .15)$

$\mathrm{KCl}$

EA

USTR

DOL

R-squared

$$
0.0304
$$

$(-0.590 .5)$

$-0.769$

$(-1.37-0.05)$

0.0242

$(-0.080 .14)$

$-0.507$

$(-1.330 .28)$

1.3024

(0.6 1.99)

0.2275
Constant

$\mathrm{KCl}$

EA

USTR

DOL

R-squared
Twelve-Month Cumulative $\mathbf{R}^{*}$ Response

$\begin{array}{cc}0.5249 & -0.1249 \\ (-0.070 .84) & (-1.410 .73) \\ & \\ 0.0421 & -1.3229 \\ (-0.71 .13) & (-2.130 .35)\end{array}$

0.0839

$(-0.10 .32)$

$-1.4347$

$(-2.80 .55)$

1.5887

(1.08 3.81)

0

0.2791
Forty Eight-Month Cumulative $\mathbf{R}^{*}$ Response

Constant

$$
0.1485
$$$$
2.4098
$$$$
(-1.281 .11)
$$$$
(-1.773 .71)
$$

$\mathrm{KCl}$

$$
\begin{gathered}
1.9563 \\
(-0.993 .89)
\end{gathered}
$$$$
0.2112
$$$$
(-1.93 .31)
$$

EA

$-0.5086$

$(-0.820 .29)$

USTR

$-4.4627$

$(-5.792 .04)$

DOL

1.5887

$(-0.044 .21)$

0.2285
$(-1.873 .04)$

R-squared

Notes: see notes in Table 2a. The estimates of $\mathrm{KCl}$ come from a $2 \mathrm{SLS}$ regression in which the Miniane capital controls measures are instrumented for with the period average of the Transparency International's Corruption Perception Index, whose values are listed in Table 1. 


\section{Table 6a: Regressions for Exchange Rate Responses under US Block Exogeneity}

Six-Month Cumulative ER Response

\begin{tabular}{|c|c|c|c|c|c|c|c|c|c|c|c|}
\hline Constant & $\begin{array}{c}1.4493 \\
(0.391 .69)\end{array}$ & $\begin{array}{c}-1.4555 \\
(-2.110 .01)\end{array}$ & $\begin{array}{c}0.9976 \\
(0.41 .06)\end{array}$ & $\begin{array}{c}1.6468 \\
(0.491 .8)\end{array}$ & $\begin{array}{c}-1.4686 \\
(-3.60 .54)\end{array}$ & Constant & $\begin{array}{c}1.1375 \\
(-1.141 .9)\end{array}$ & $\begin{array}{c}-2.8703 \\
(-4.60 .6)\end{array}$ & $\begin{array}{c}0.4563 \\
(-0.830 .69)\end{array}$ & $\begin{array}{c}0.8446 \\
(-1.691 .46)\end{array}$ & $\begin{array}{c}-6.19 \\
(-10.67-0.55)\end{array}$ \\
\hline KC & $\begin{array}{c}-1.2961 \\
(-1.850 .1)\end{array}$ & & & & $\begin{array}{c}0.6062 \\
(-0.871 .88)\end{array}$ & $\mathrm{KC}$ & $\begin{array}{c}-1.5757 \\
(-3.341 .47)\end{array}$ & & & & $\begin{array}{c}0.3486 \\
(-3.362 .91)\end{array}$ \\
\hline EA & & $\begin{array}{c}0.6669 \\
(0.150 .83)\end{array}$ & & & $\begin{array}{c}0.6852 \\
(0.161 .02)\end{array}$ & EA & & $\begin{array}{c}0.9559 \\
(-0.241 .41)\end{array}$ & & & $\begin{array}{c}1.5859 \\
(0.22 .28)\end{array}$ \\
\hline USTR & & & $\begin{array}{c}-3.594 \\
(-4.3-0.45)\end{array}$ & & $\begin{array}{c}-2.0644 \\
(-3.760 .69)\end{array}$ & USTR & & & $\begin{array}{c}-2.577 \\
(-4.744 .95)\end{array}$ & & $\begin{array}{c}-3.423 \\
(-7.63 .41)\end{array}$ \\
\hline DOL & & & & $\begin{array}{c}-2.0715 \\
(-2.6-0.13)\end{array}$ & $\begin{array}{c}-0.5217 \\
(-1.581 .44)\end{array}$ & DOL & & & & $\begin{array}{c}-1.3103 \\
(-3.133 .09)\end{array}$ & $\begin{array}{c}2.9729 \\
(-0.397 .72)\end{array}$ \\
\hline R-squared & 0.0853 & 0.1907 & 0.065 & 0.1466 & 0.2303 & R-squared & 0.0206 & 0.0639 & 0.0054 & 0.0095 & 0.0872 \\
\hline & Twenty & Four-Mont & th Cumula & ative ER $R$ & Response & & Forty Ei & :ight-Mont & th Cumulat & tive ER Res & sponse \\
\hline Constant & $\begin{array}{c}0.4266 \\
(-2.942 .81)\end{array}$ & $\begin{array}{c}-6.1311 \\
(-10.091 .45)\end{array}$ & $\begin{array}{c}-0.3134 \\
(-2.070 .87)\end{array}$ & $\begin{array}{c}-0.2062 \\
(-3.912 .22)\end{array}$ & $\begin{array}{c}-14.682 \\
(-20.8-0.16)\end{array}$ & Constant & $\begin{array}{c}2.1558 \\
(-2.267 .37)\end{array}$ & $\begin{array}{c}-12.5836 \\
(-21.522 .56)\end{array}$ & $\begin{array}{c}1.653 \\
(-1.363 .92)\end{array}$ & $\begin{array}{c}3.9444 \\
(-1.928 .82)\end{array}$ & $\begin{array}{c}-22.0321 \\
(-32.617 .51)\end{array}$ \\
\hline KC & $\begin{array}{c}-2.1677 \\
(-6.543 .31)\end{array}$ & & & & $\begin{array}{c}0.7678 \\
(-7.235 .91)\end{array}$ & KC & $\begin{array}{c}-4.697 \\
(-14.684 .62)\end{array}$ & & & & $\begin{array}{c}7.7826 \\
(-8.2113 .5)\end{array}$ \\
\hline EA & & $\begin{array}{c}1.6332 \\
(-0.642 .76)\end{array}$ & & & $\begin{array}{c}3.2625 \\
(0.034 .34)\end{array}$ & EA & & $\begin{array}{c}3.7004 \\
(-0.596 .13)\end{array}$ & & & $\begin{array}{c}5.6108 \\
(-0.677 .47)\end{array}$ \\
\hline USTR & & & $\begin{array}{c}-6.2201 \\
(-12.587 .73)\end{array}$ & & $\begin{array}{c}-10.0243 \\
(-17.494 .36)\end{array}$ & USTR & & & $\begin{array}{c}-28.4172 \\
(-38.921 .28)\end{array}$ & & $\begin{array}{c}-22.5862 \\
(-35.024 .83)\end{array}$ \\
\hline DOL & & & & $\begin{array}{c}-1.2815 \\
(-6.86 .52)\end{array}$ & $\begin{array}{c}7.9742 \\
(-1.3615 .39)\end{array}$ & DOL & & & & $\begin{array}{c}-9.938 \\
(-20.395 .48)\end{array}$ & $\begin{array}{c}1.2278 \\
(-13.74 \quad 15.4)\end{array}$ \\
\hline R-squared & 0.0089 & 0.0426 & 0.0073 & 0.0021 & 0.0806 & R-squared & 0.0131 & 0.0687 & 0.0478 & 0.0395 & 0.1156 \\
\hline
\end{tabular}

Notes: see notes in Table $2 a$. 


\section{Table 6b: Regressions for Interest Rate Responses under US Block Exogeneity}

Six-Month Cumulative $\mathbf{R}^{*}$ Response

$\begin{array}{lccccc}\text { Constant } & -0.035 & 0.8118 & 0.2055 & -0.159 & -0.3192 \\ & (-0.230 .14) & (0.221 .39) & (0.110 .27) & (-0.370 .03) & (-0.80 .17) \\ \text { KC } & & & & & \\ & 0.5205 & & & -0.0823 \\ & (0.080 .94) & & & (-0.440 .22) \\ \text { EA } & & & & \\ & & -0.1704 & & 0.0397 \\ \text { USTR } & (-0.33-0.02) & & (-0.070 .15) \\ & & & & & \\ & & & 0.641 & & 0.6094 \\ \text { DOL } & & & 0.071 .24) & & (-1.230 .06) \\ & & & & 0.933 & 1.2054 \\ \text { R-squared } & 0.0673 & 0.0607 & 0.0102 & 0.1455 & 0.1535\end{array}$

Twenty Four-Month Cumulative $\mathbf{R}^{\star}$ Response

\begin{tabular}{|c|c|c|c|c|c|c|c|c|c|c|c|}
\hline Constant & $\begin{array}{c}0.1696 \\
(-0.50 .96)\end{array}$ & $\begin{array}{c}3.2139 \\
(0.074 .56)\end{array}$ & $\begin{array}{c}1.4293 \\
(0.861 .44)\end{array}$ & $\begin{array}{c}0.1421 \\
(-0.51 .02)\end{array}$ & $\begin{array}{c}0.3631 \\
(-1.692 .49)\end{array}$ & Constant & $\begin{array}{c}-0.0967 \\
(-1.151 .16)\end{array}$ & $\begin{array}{c}3.995 \\
(-1.326 .17)\end{array}$ & $\begin{array}{c}1.9082 \\
(0.851 .8)\end{array}$ & $\begin{array}{c}0.6459 \\
(-0.761 .8)\end{array}$ & $\begin{array}{c}2.554 \\
(-1.955 .08)\end{array}$ \\
\hline KC & $\begin{array}{c}1.9168 \\
(-0.443 .1)\end{array}$ & & & & $\begin{array}{c}-0.1112 \\
(-1.61 .4)\end{array}$ & KC & $\begin{array}{c}2.6179 \\
(-1.374 .55)\end{array}$ & & & & $\begin{array}{c}1.2312 \\
(-1.683 .01)\end{array}$ \\
\hline EA & & $\begin{array}{c}-0.6048 \\
(-1.010 .18)\end{array}$ & & & $\begin{array}{c}-0.0438 \\
(-0.510 .46)\end{array}$ & EA & & $\begin{array}{c}-0.8059 \\
(-1.450 .53)\end{array}$ & & & $\begin{array}{c}-0.4775 \\
(-1.040 .48)\end{array}$ \\
\hline USTR & & & $\begin{array}{c}-2.7177 \\
(-6.10 .64)\end{array}$ & & $\begin{array}{c}-6.6754 \\
(-8.69-2.08)\end{array}$ & USTR & & & $\begin{array}{c}-7.5729 \\
(-12.731 .11)\end{array}$ & & $\begin{array}{c}-9.5715 \\
(-13.1-1.19)\end{array}$ \\
\hline DOL & & & & $\begin{array}{c}2.4636 \\
(-0.673 .96)\end{array}$ & $\begin{array}{c}3.5422 \\
(0.324 .48)\end{array}$ & DOL & & & & $\begin{array}{c}1.5965 \\
(-3.024 .77)\end{array}$ & $\begin{array}{c}0.8792 \\
(-2.623 .86)\end{array}$ \\
\hline R-squared & 0.1073 & 0.0903 & 0.0215 & 0.1192 & 0.2246 & R-squared & 0.1548 & 0.124 & 0.1292 & 0.0387 & 0.3309 \\
\hline
\end{tabular}

Notes: see notes in Table $2 a$.

\section{Twelve-Month Cumulative $\mathbf{R}^{*}$ Response}

\begin{tabular}{|c|c|c|c|c|c|}
\hline \multirow[t]{2}{*}{ Constant } & 0.1291 & 1.6892 & 0.6254 & -0.1414 & -0.3835 \\
\hline & $(-0.250 .55)$ & (0.19 2.66) & $(0.390 .72)$ & $\left(\begin{array}{lll}-0.51 & 0.34\end{array}\right)$ & $(-1.360 .78)$ \\
\hline \multirow[t]{2}{*}{ KC } & 0.94 & & & & -0.4947 \\
\hline & $(-0.181 .74)$ & & & & $(-1.30 .26)$ \\
\hline \multirow[t]{2}{*}{ EA } & & -0.3171 & & & 0.0748 \\
\hline & & $(-0.590 .07)$ & & & $(-0.170 .3)$ \\
\hline \multirow[t]{2}{*}{ USTR } & & & 0.316 & & -2.5885 \\
\hline & & & $(-1.191 .62)$ & & $(-3.87-0.73)$ \\
\hline \multirow[t]{2}{*}{ DOL } & & & & 1.7906 & 2.8351 \\
\hline & & & & $(0.222 .77)$ & $(1.293 .7)$ \\
\hline R-squared & 0.0693 & 0.0667 & 0.0008 & 0.169 & 0.2091 \\
\hline
\end{tabular}

Forty Eight-Month Cumulative $\mathbf{R}^{\star}$ Response 
Figure 1: Malaysia Before and After Controls

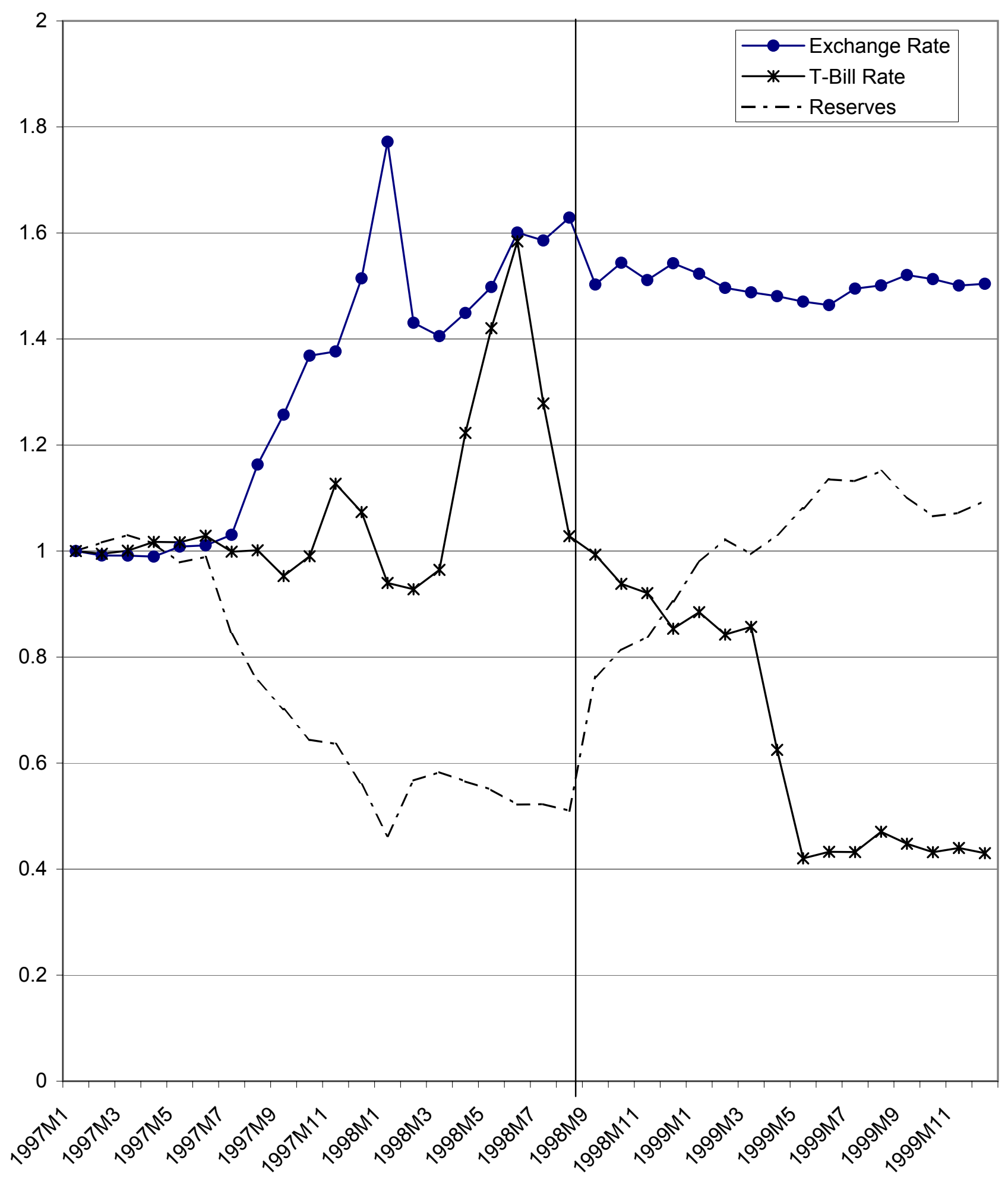


Figure 2: Comparison of Panel Impulse Responses
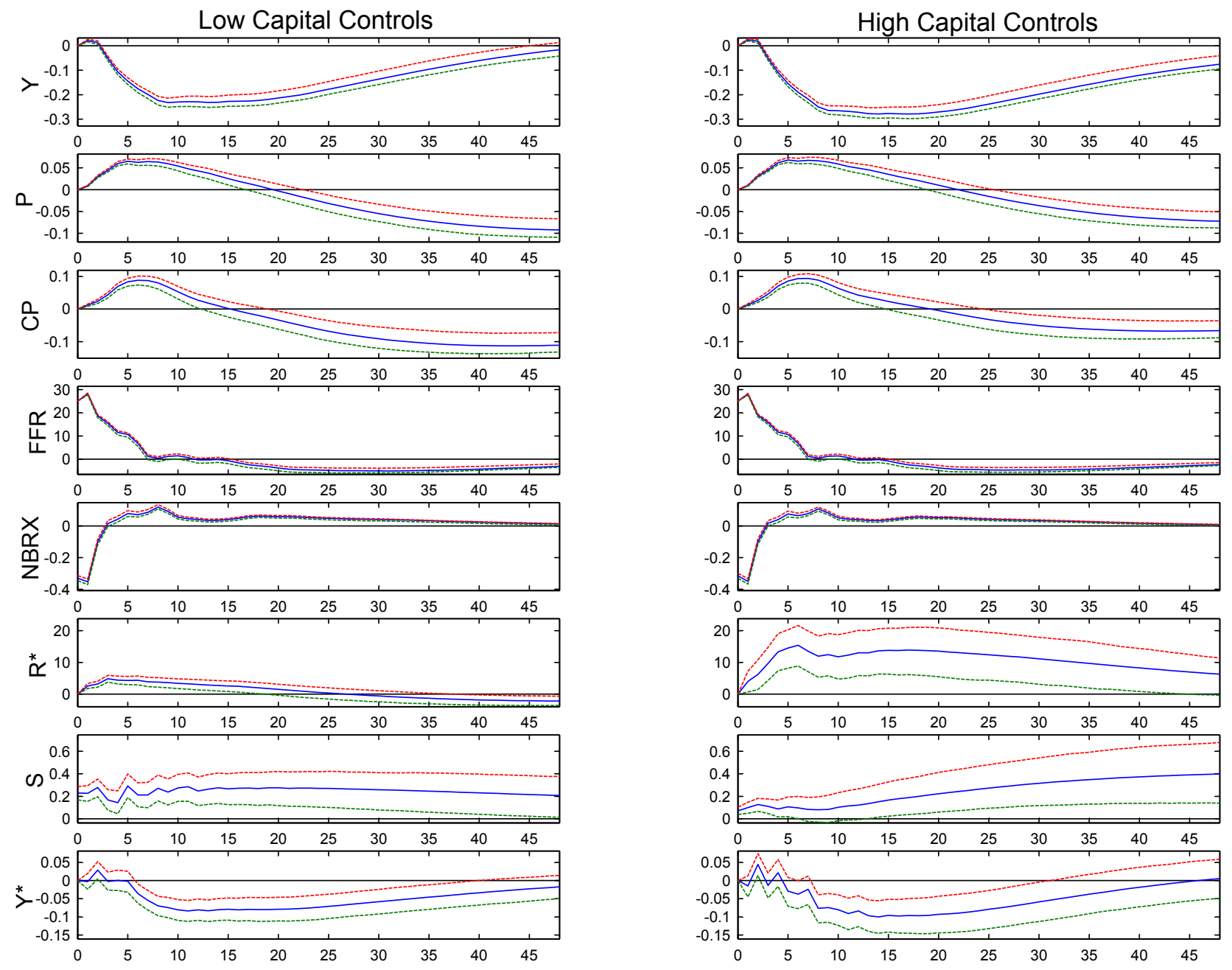
Figure 2b: Comparison excluding Turkey and Mexico
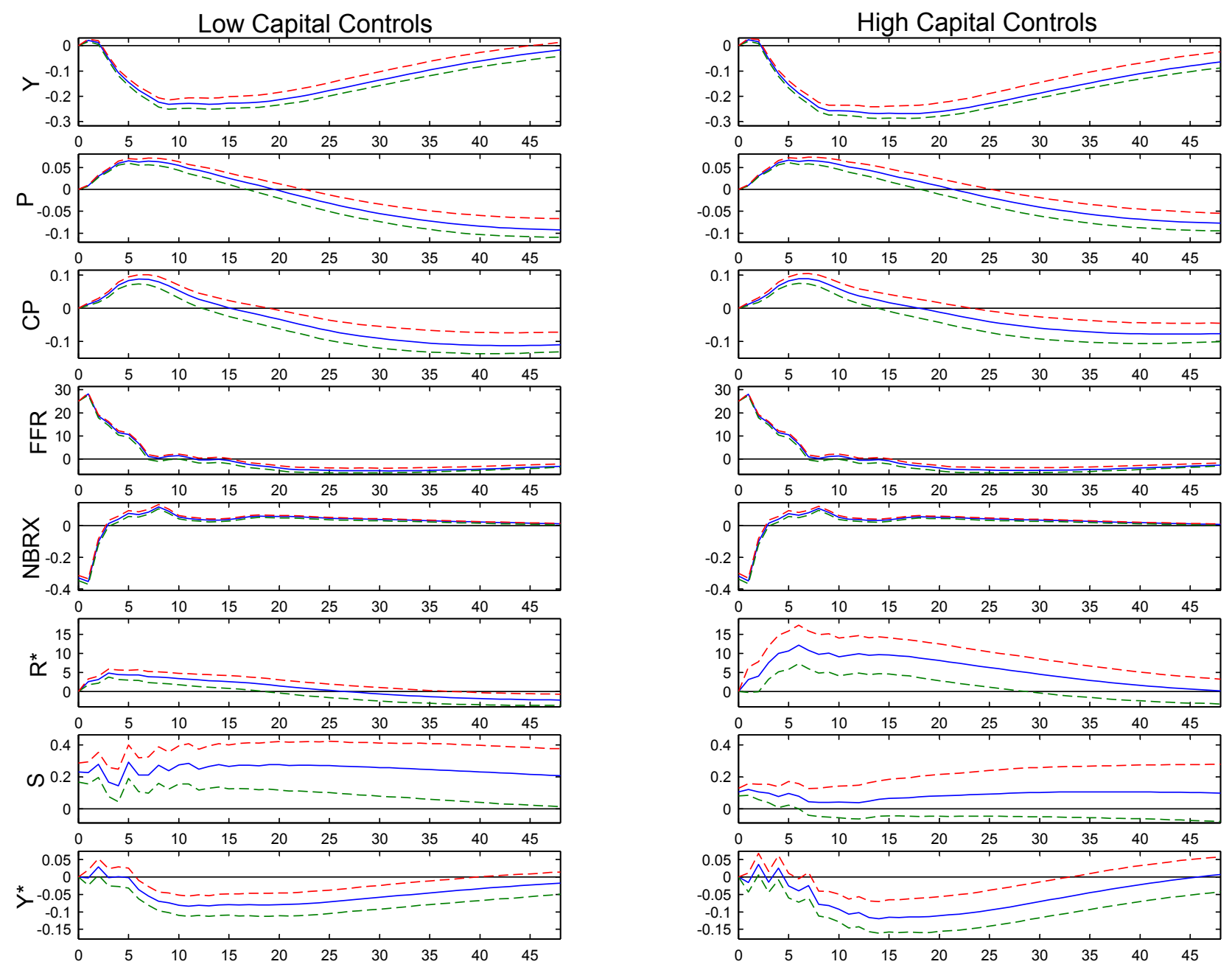
Figure 3: Comparison of Interest Rate Responses
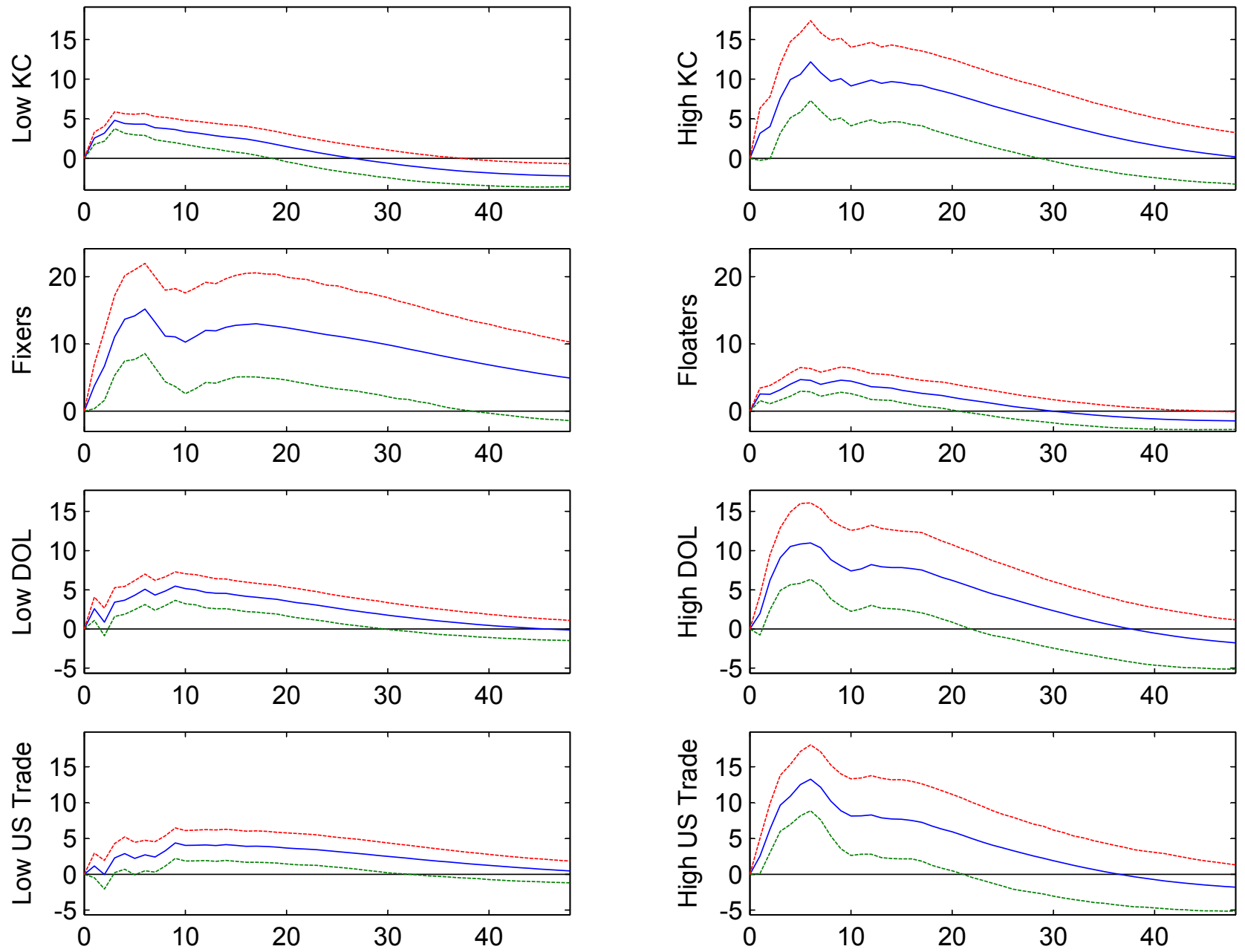
Figure 4: Comparison of Exchange Rate Responses
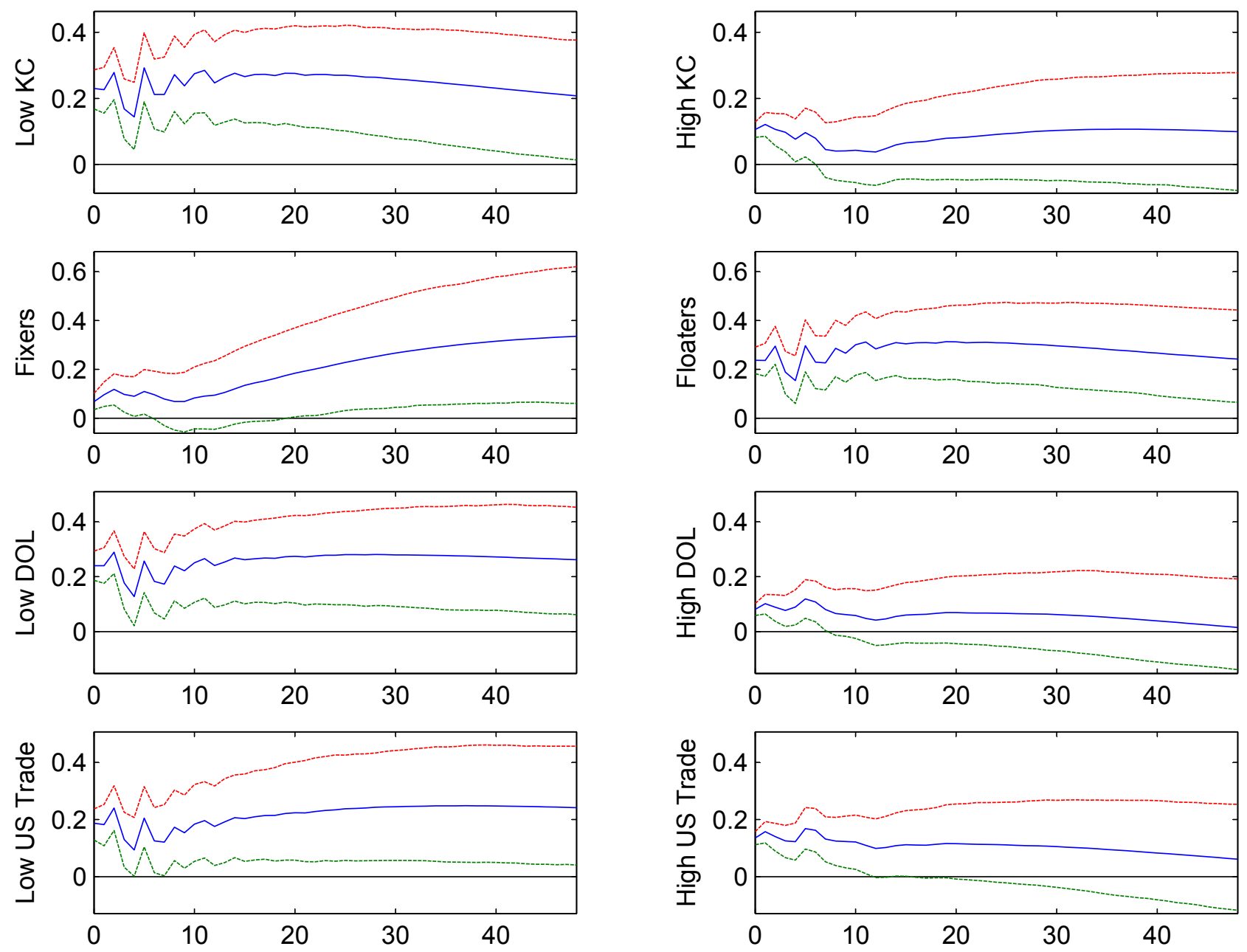
Figure 5: Comparison using the Lane and Milesi-Ferretti measure
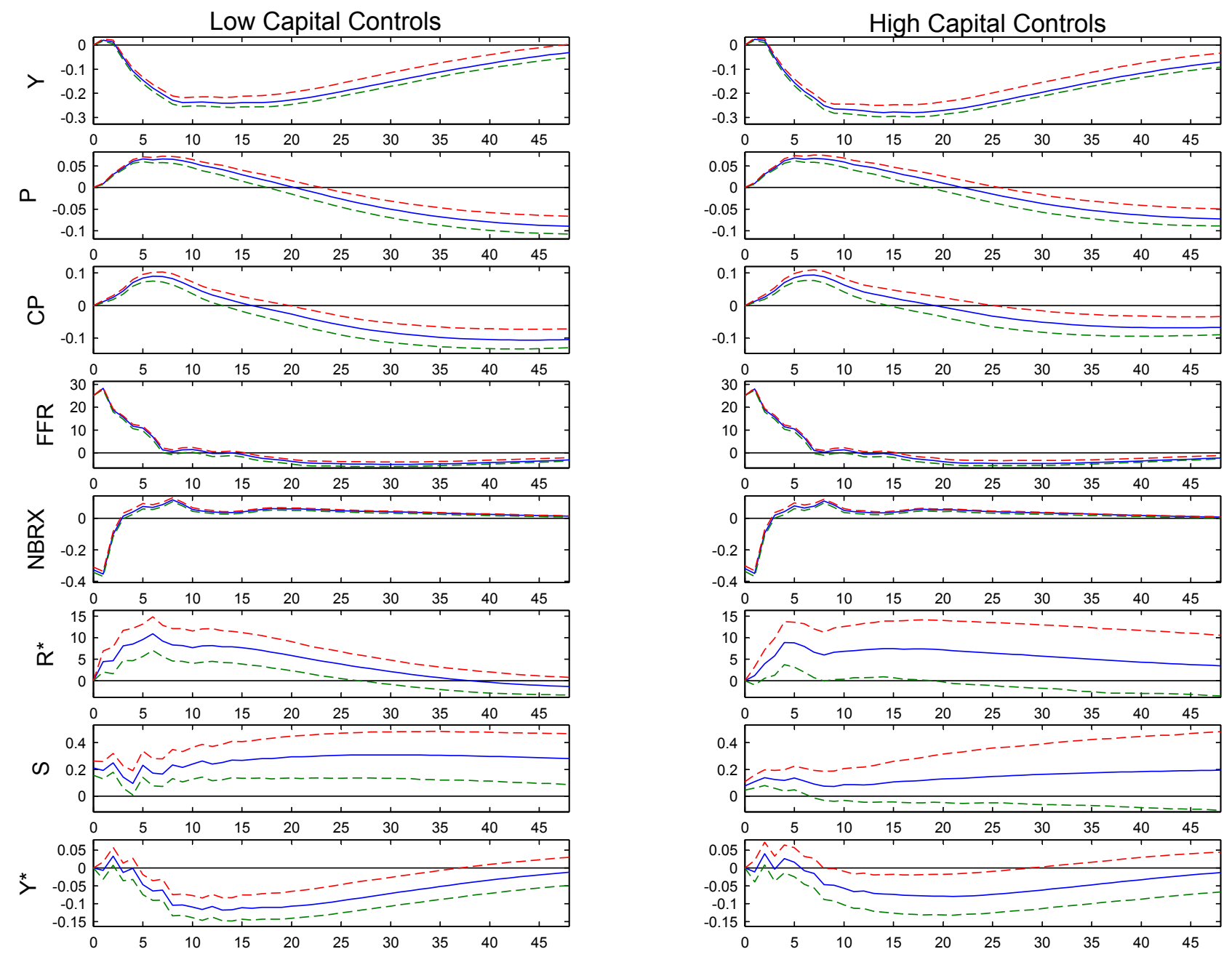


\section{Appendix 1: Impulse responses for all countries}
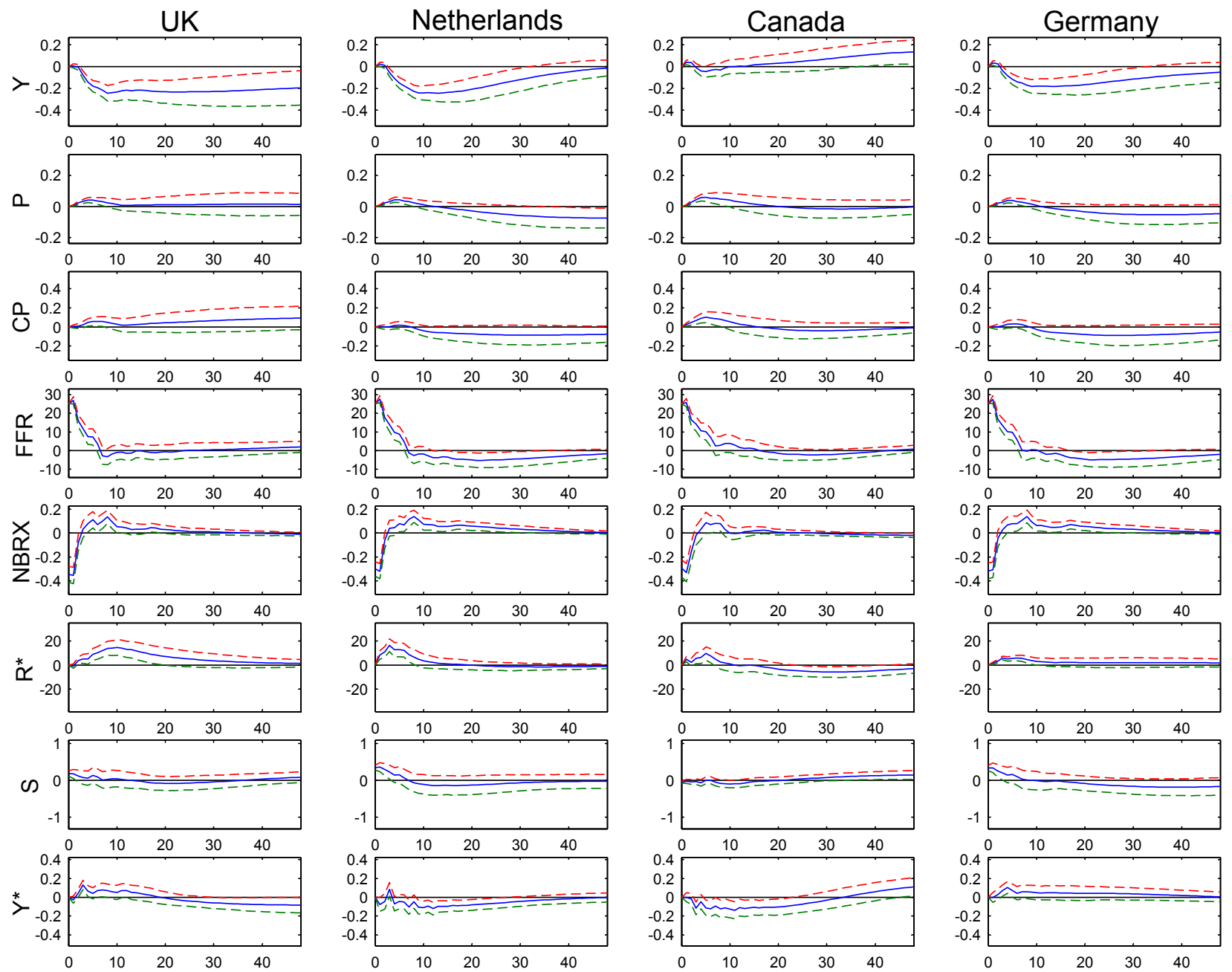

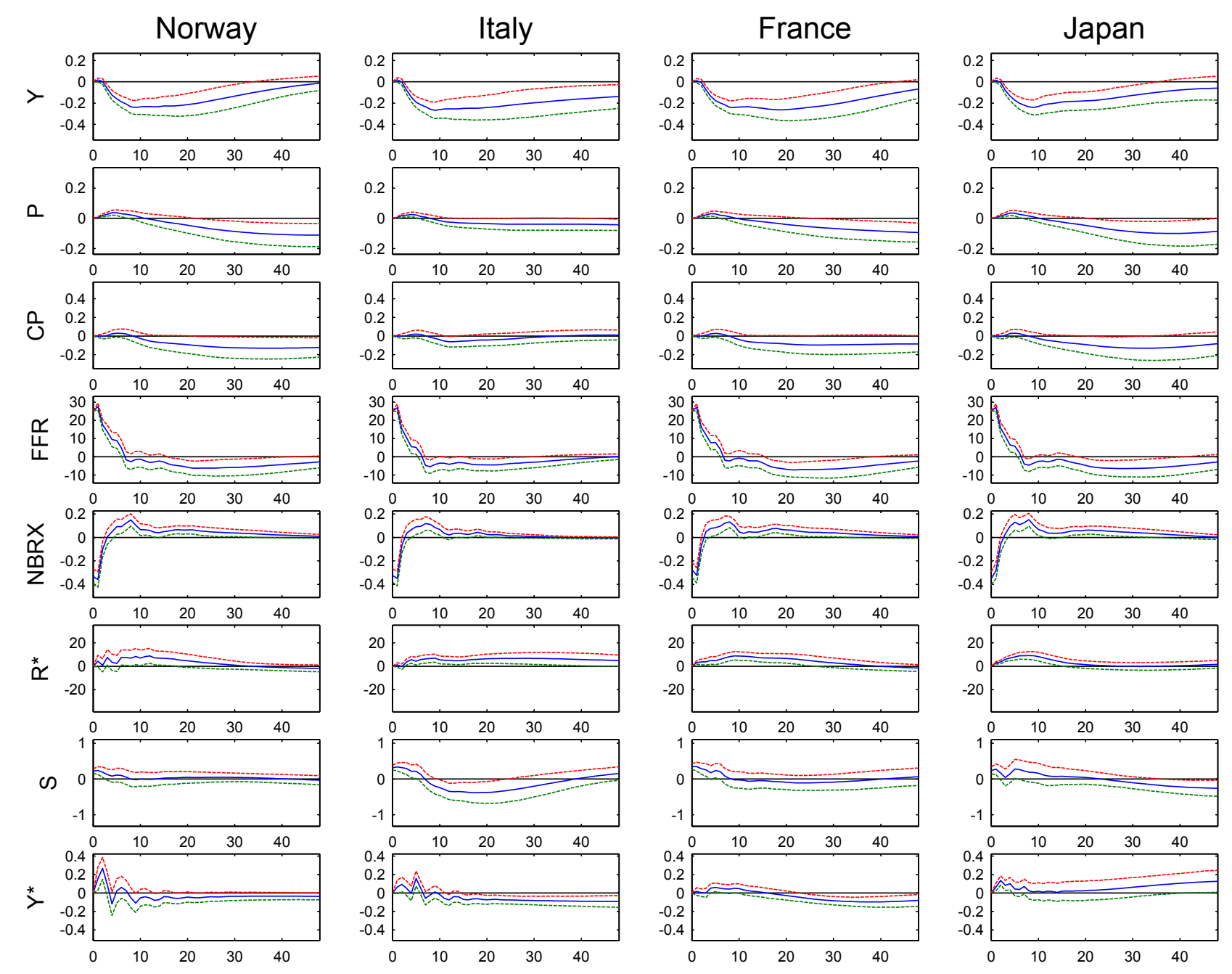
Austria

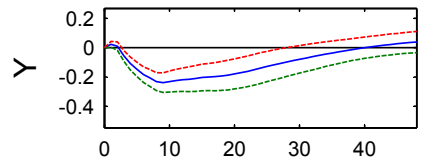

ㅇ
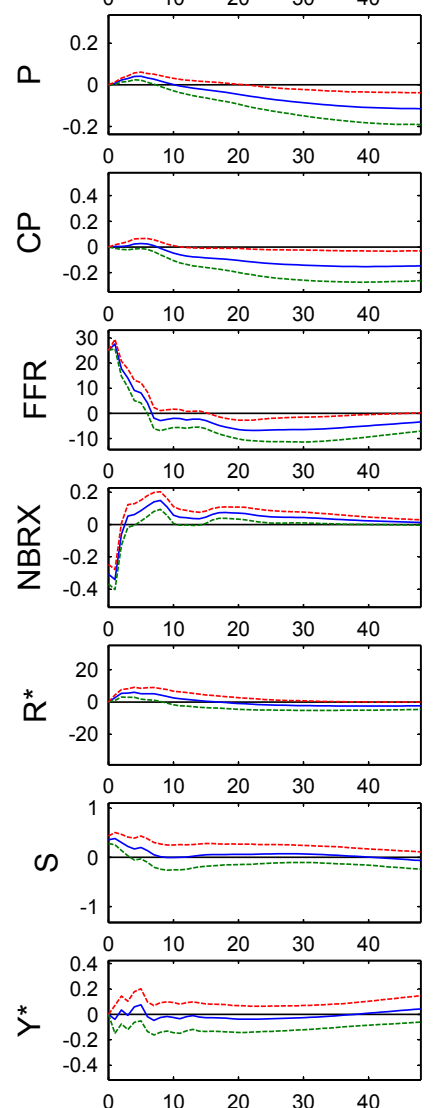

Australia
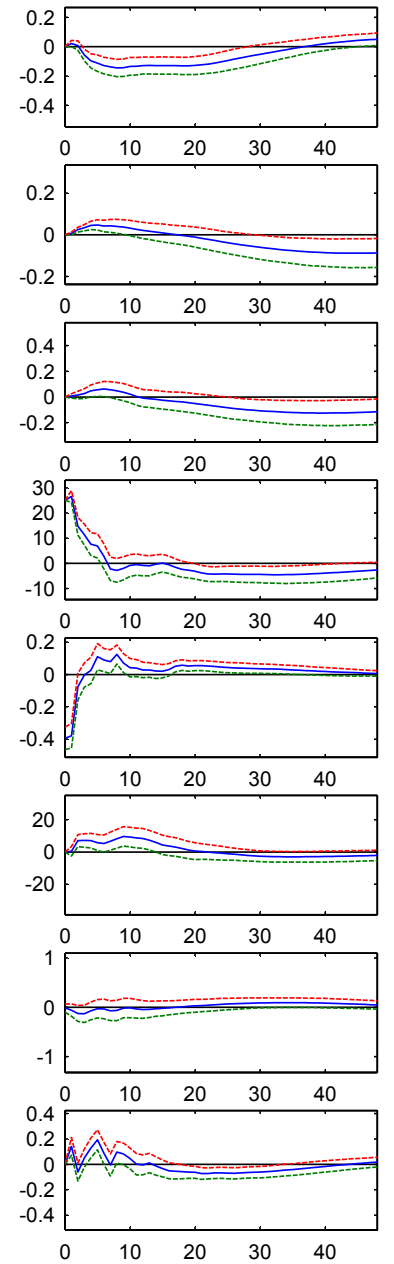

Portugal
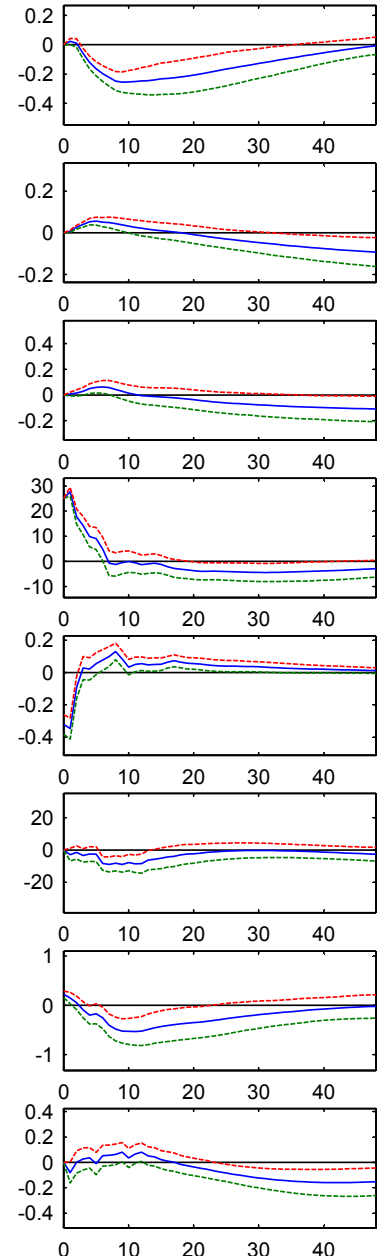

Sweden
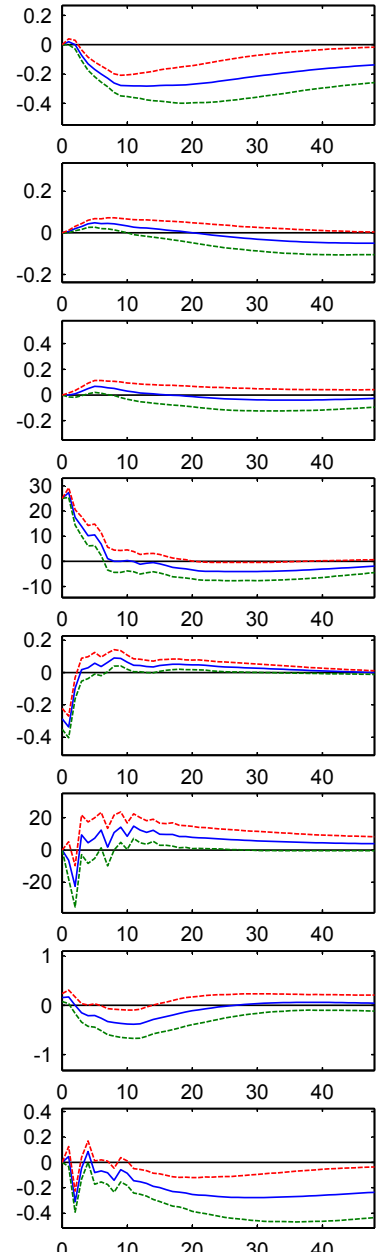


\section{Greece}

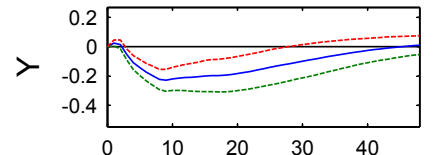

ㅇ
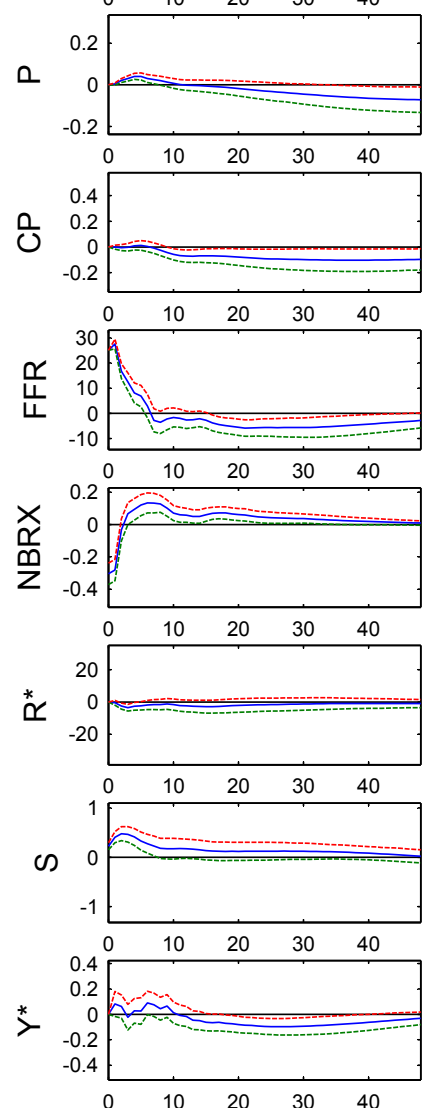

Belgium
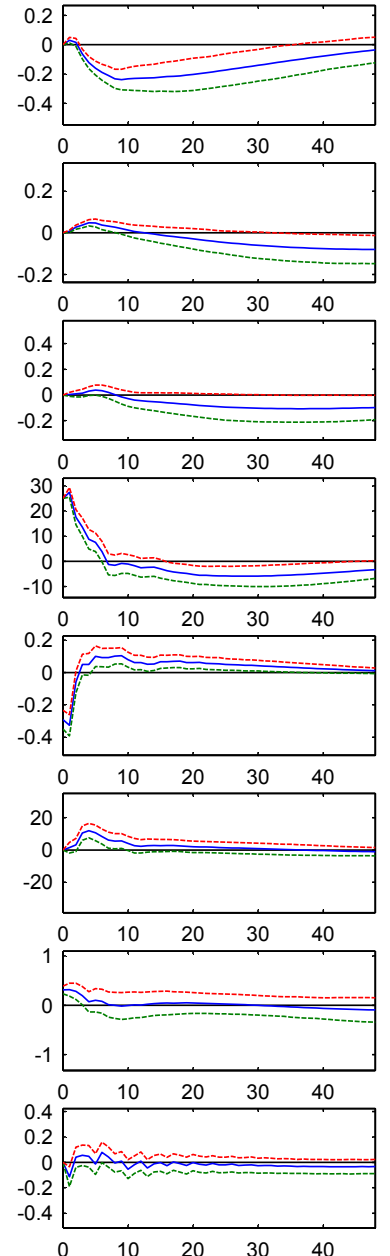

Finland
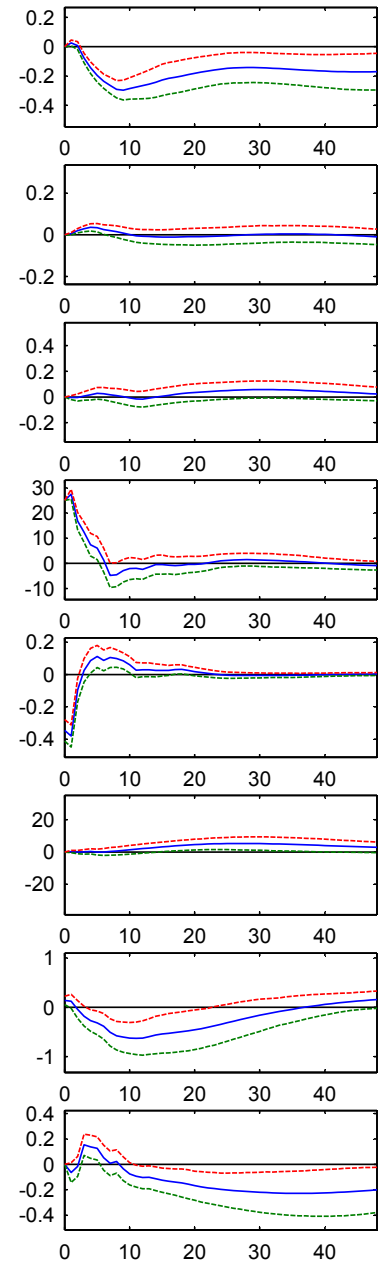

Spain
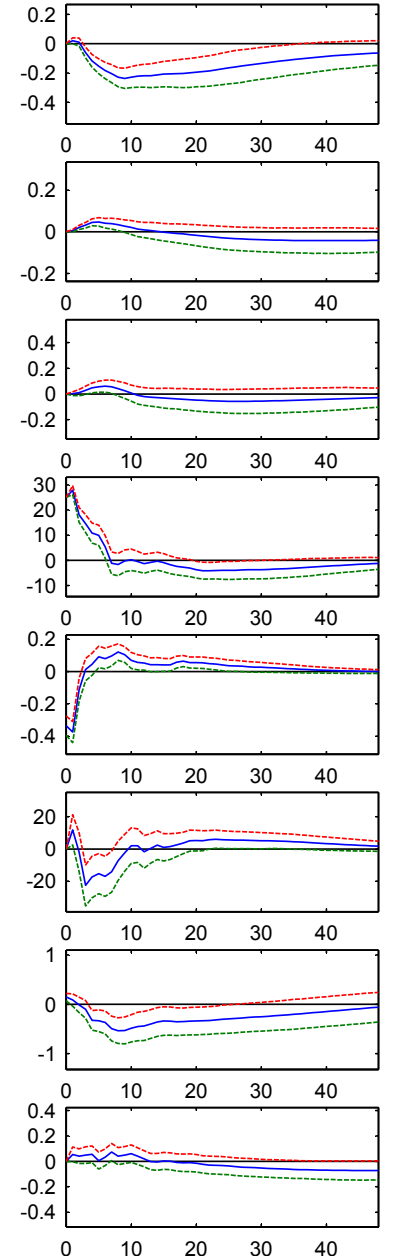

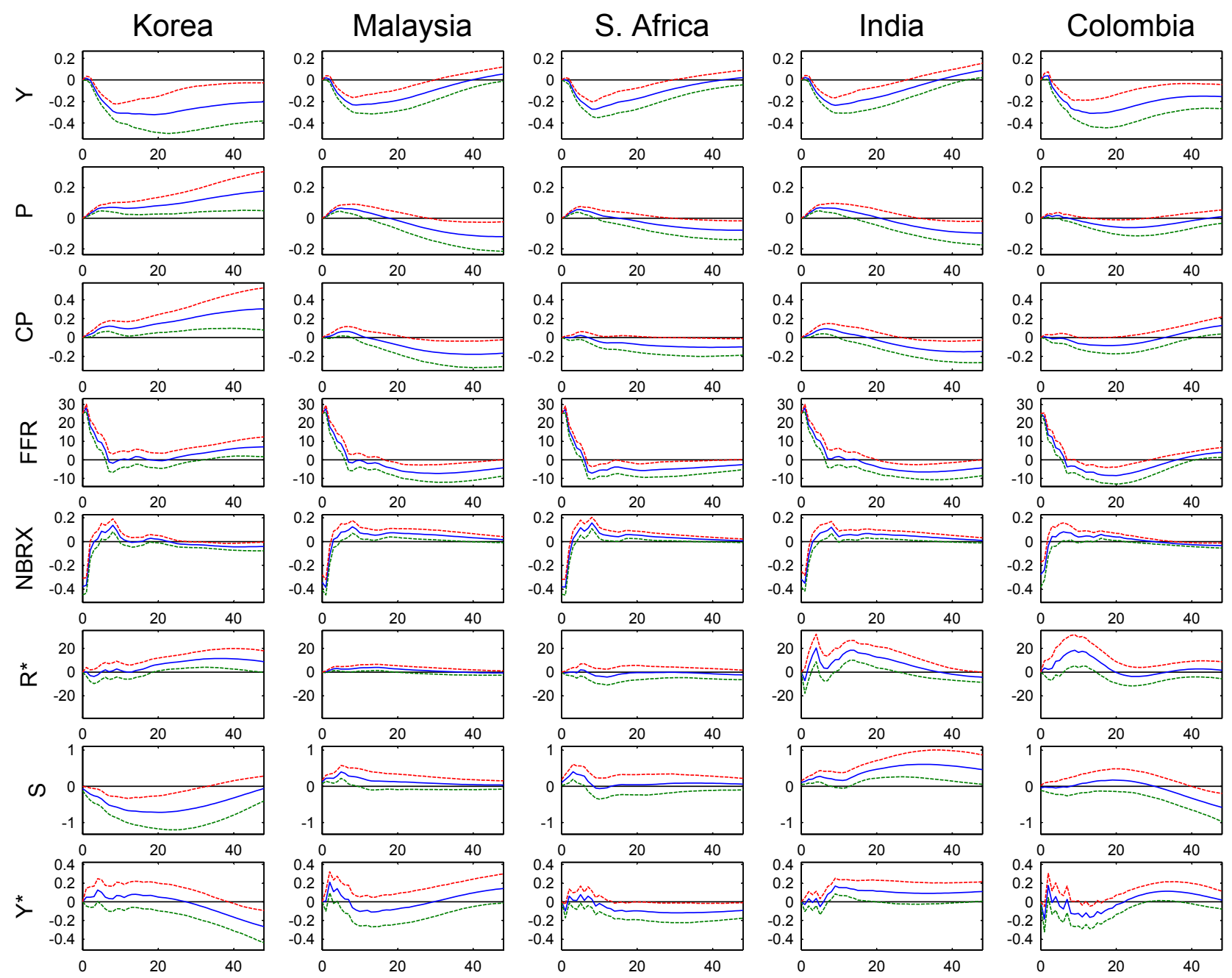

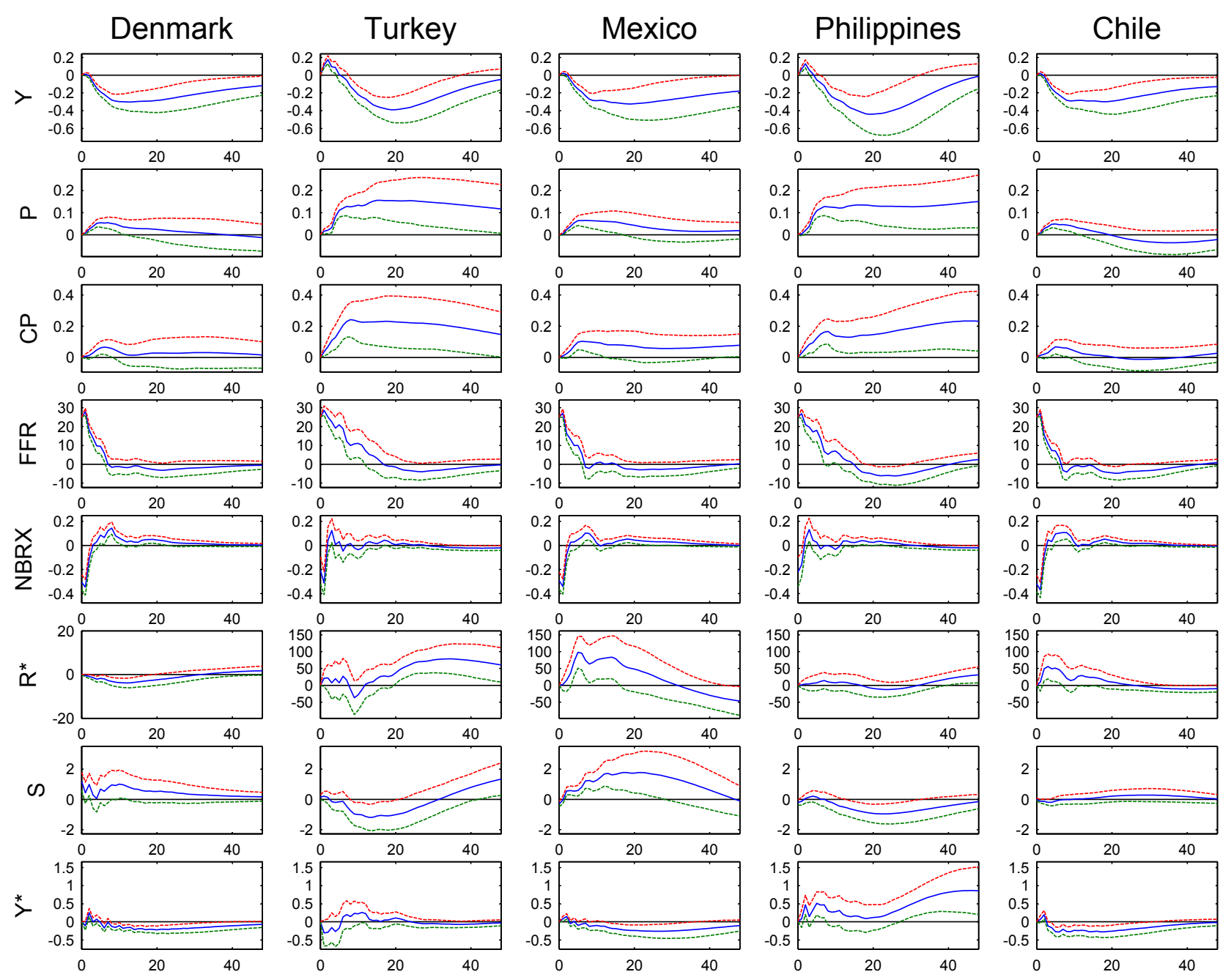


\section{Appendix 2: Comparison for the sub-period 1975-90}

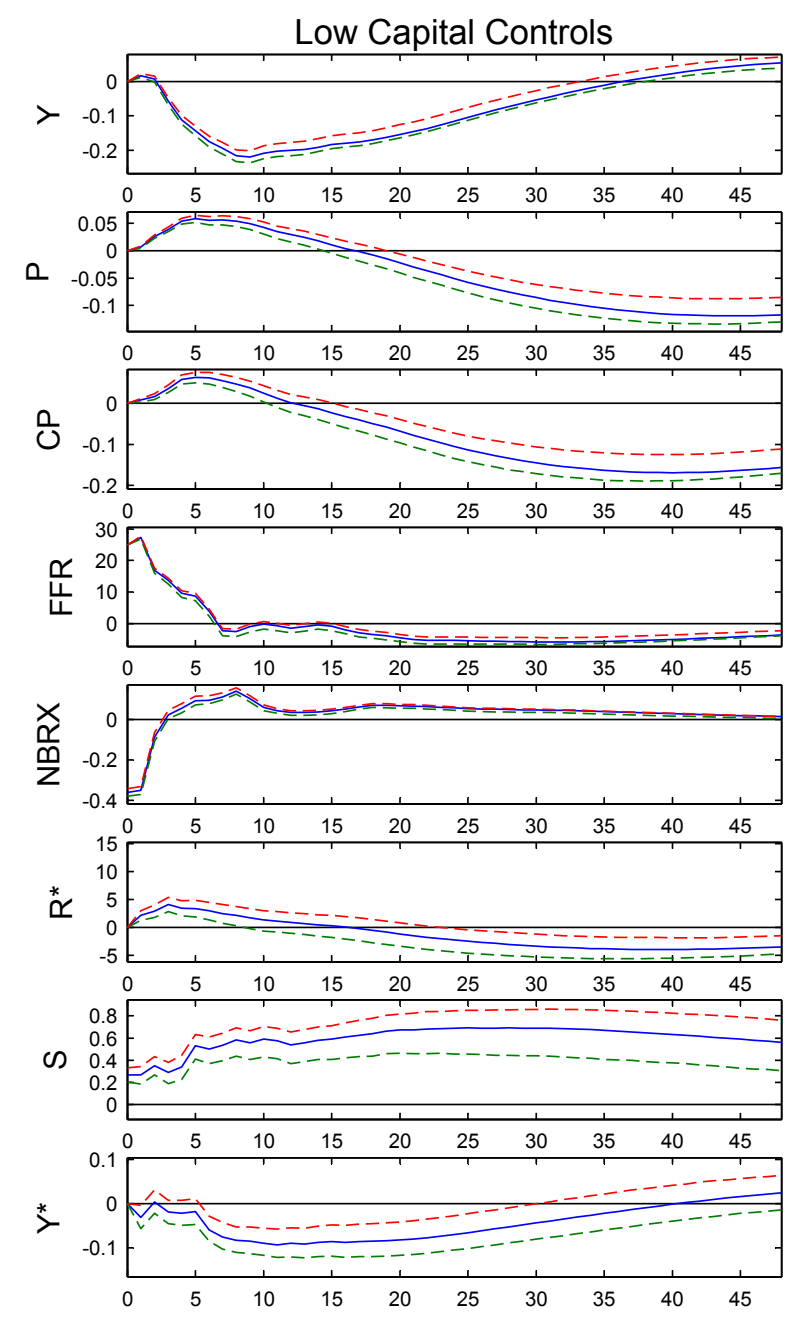

High Capital Controls

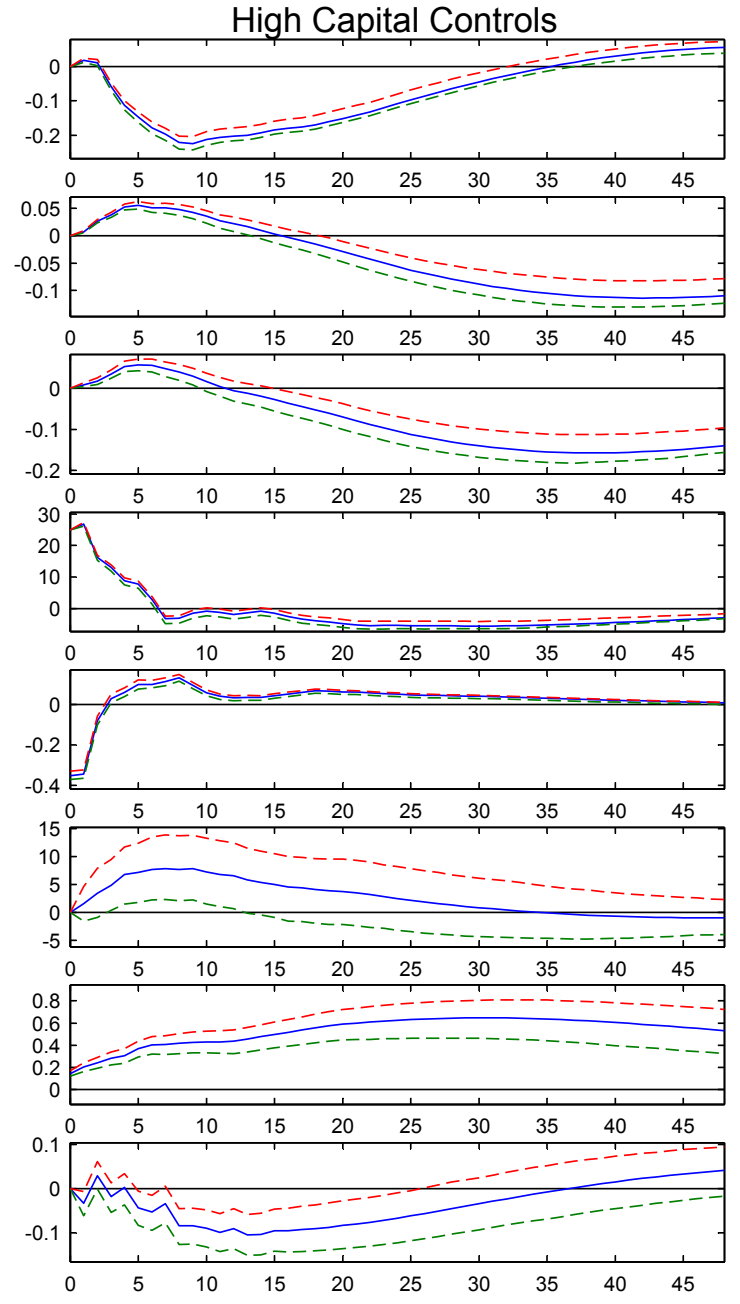




\section{Comparison for the sub-period 1976-91}
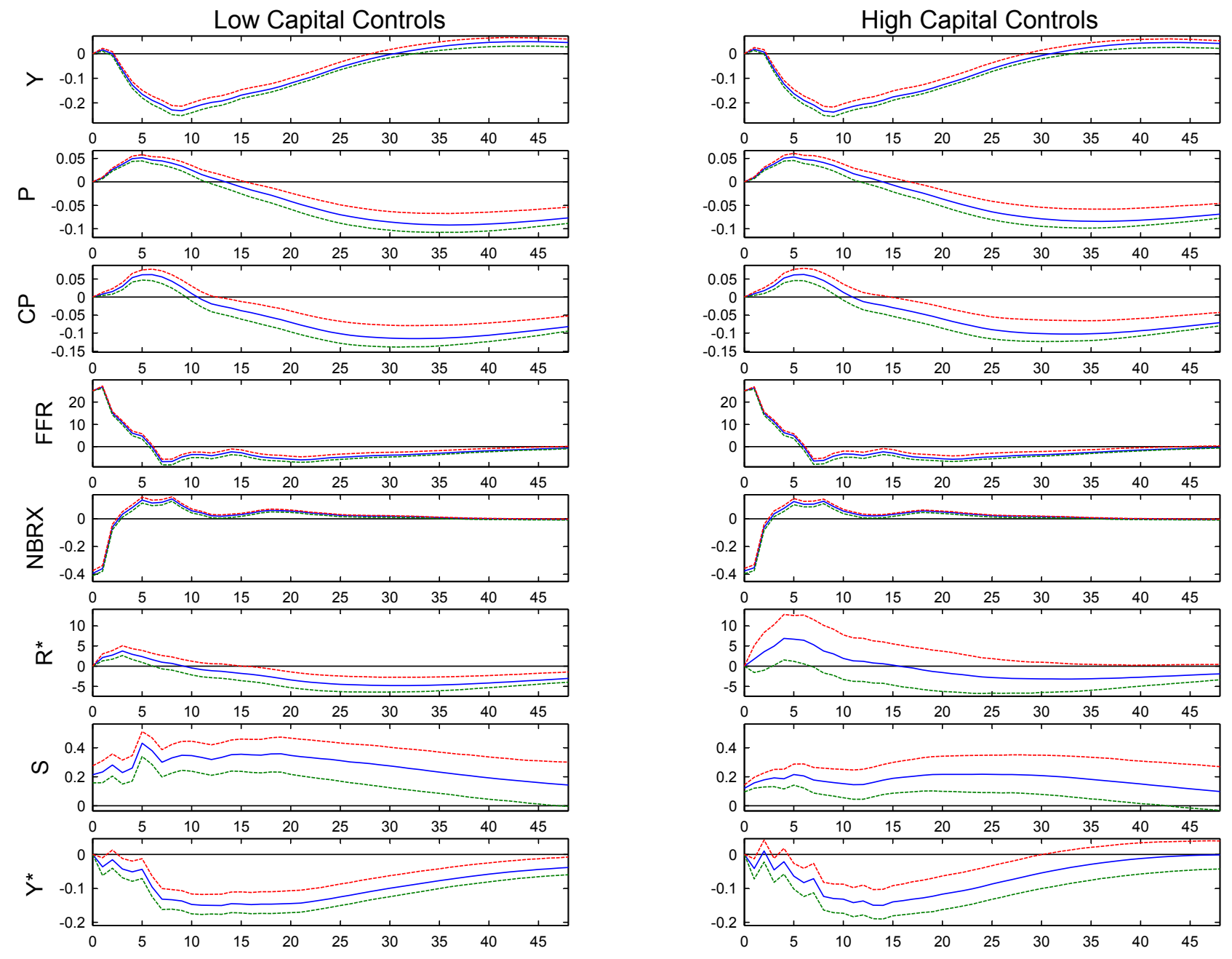


\section{Comparison for the sub-period 1977-92}
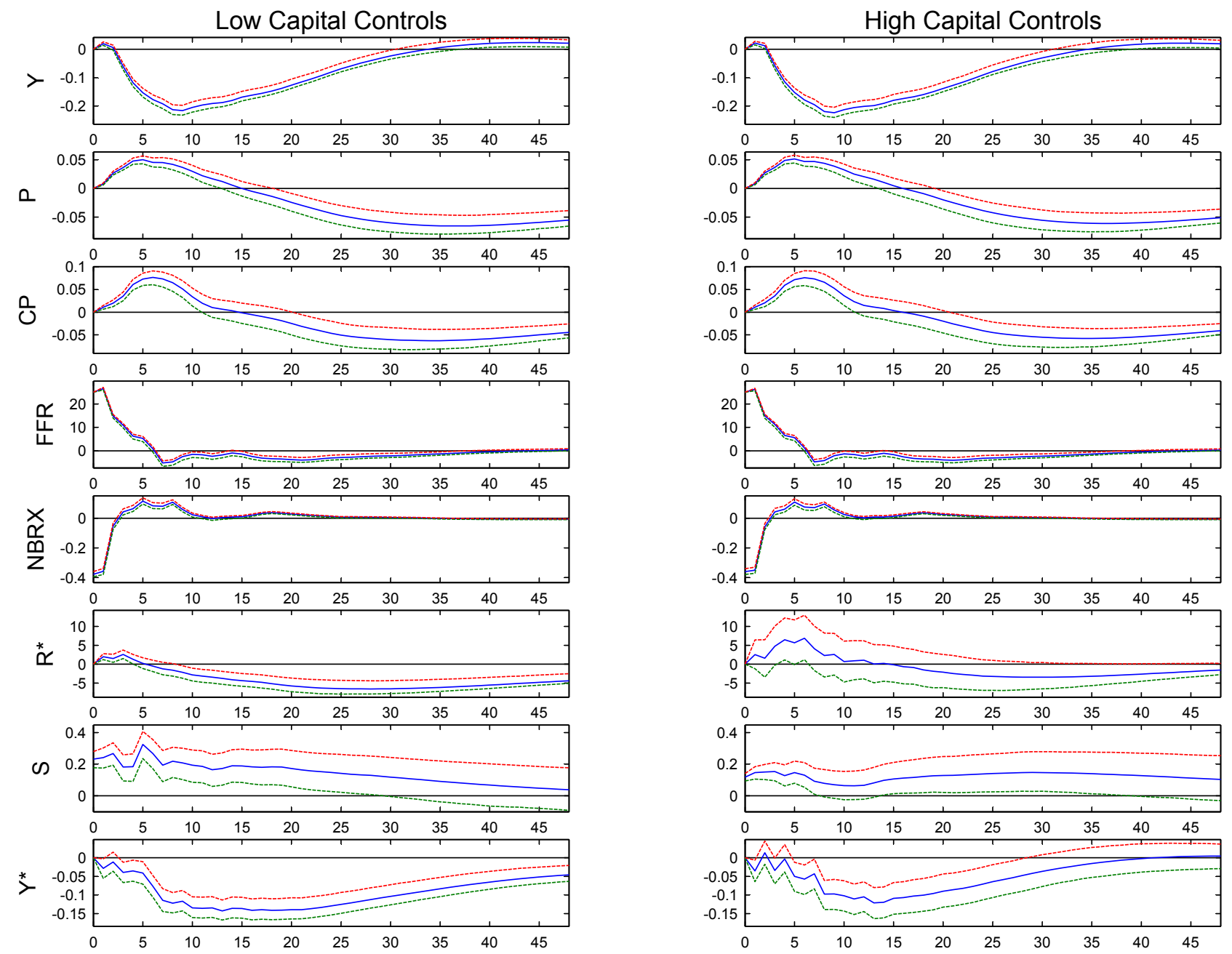


\section{Comparison for the sub-period 1978-93}
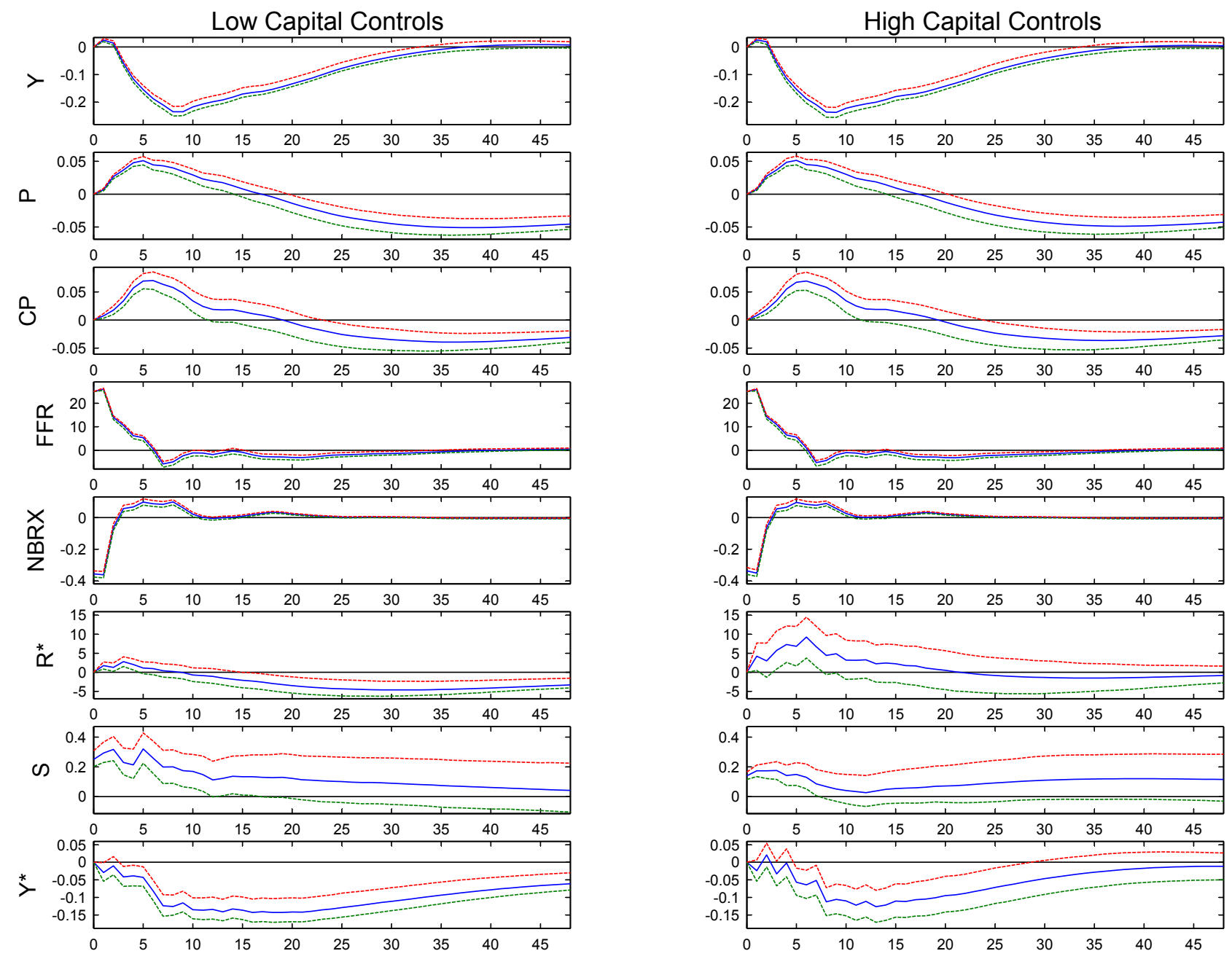
Comparison for the sub-period 1979-94
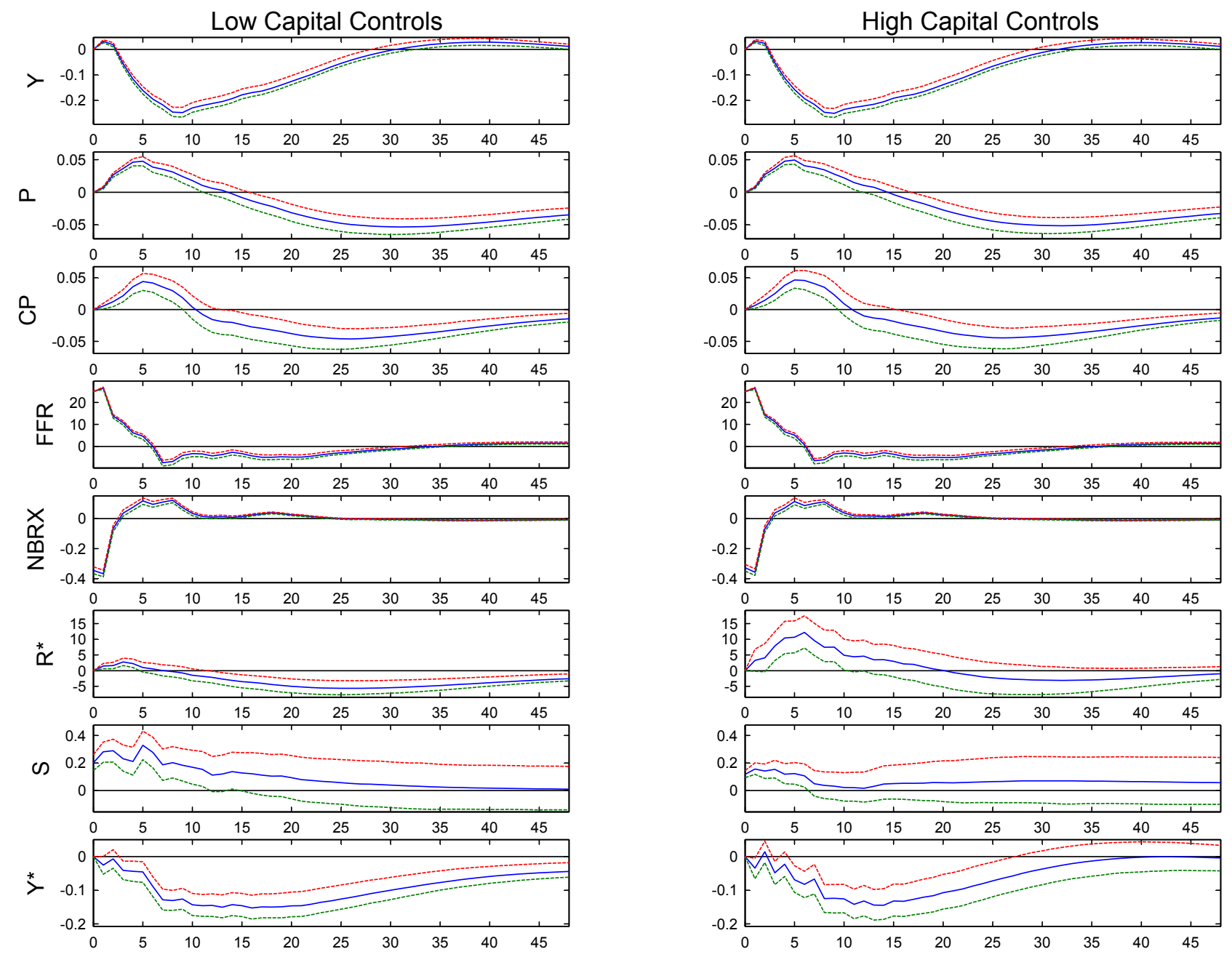


\section{Comparison for the sub-period 1980-95}

Low Capital Controls

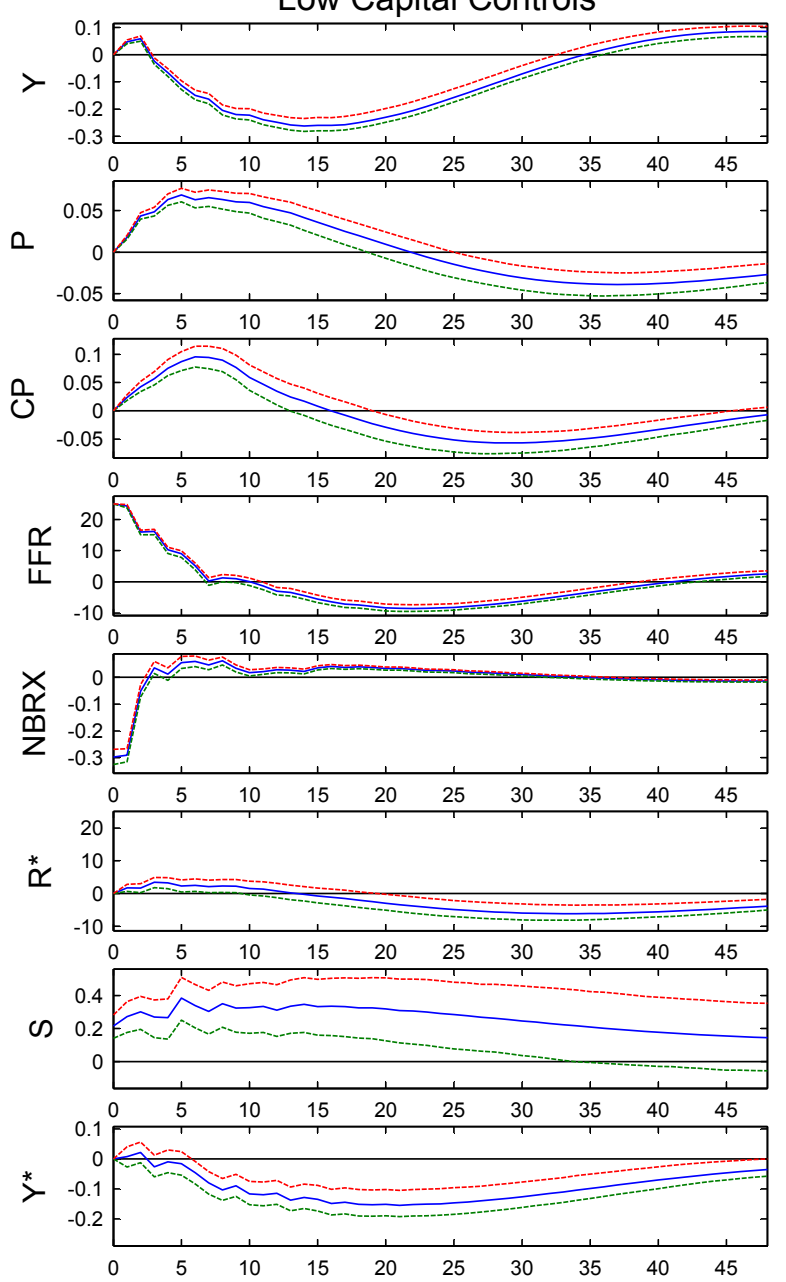

High Capital Controls
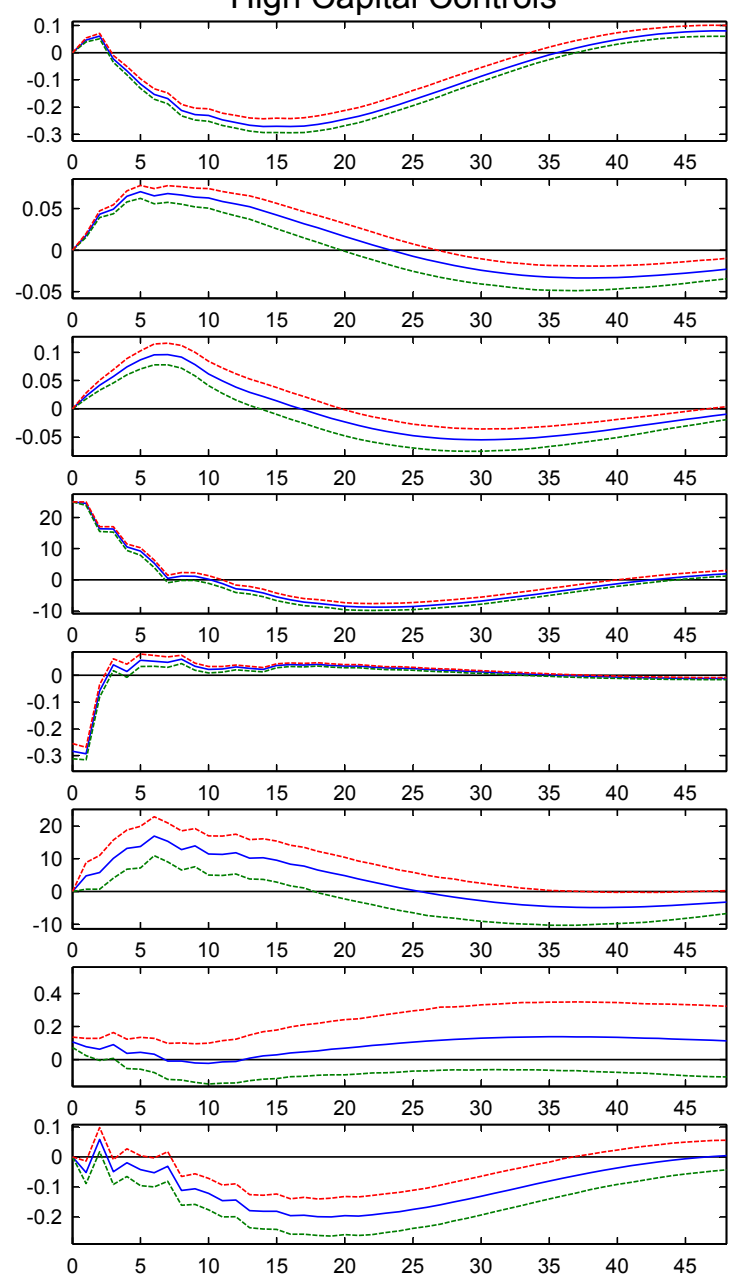
Comparison for the sub-period 1981-96
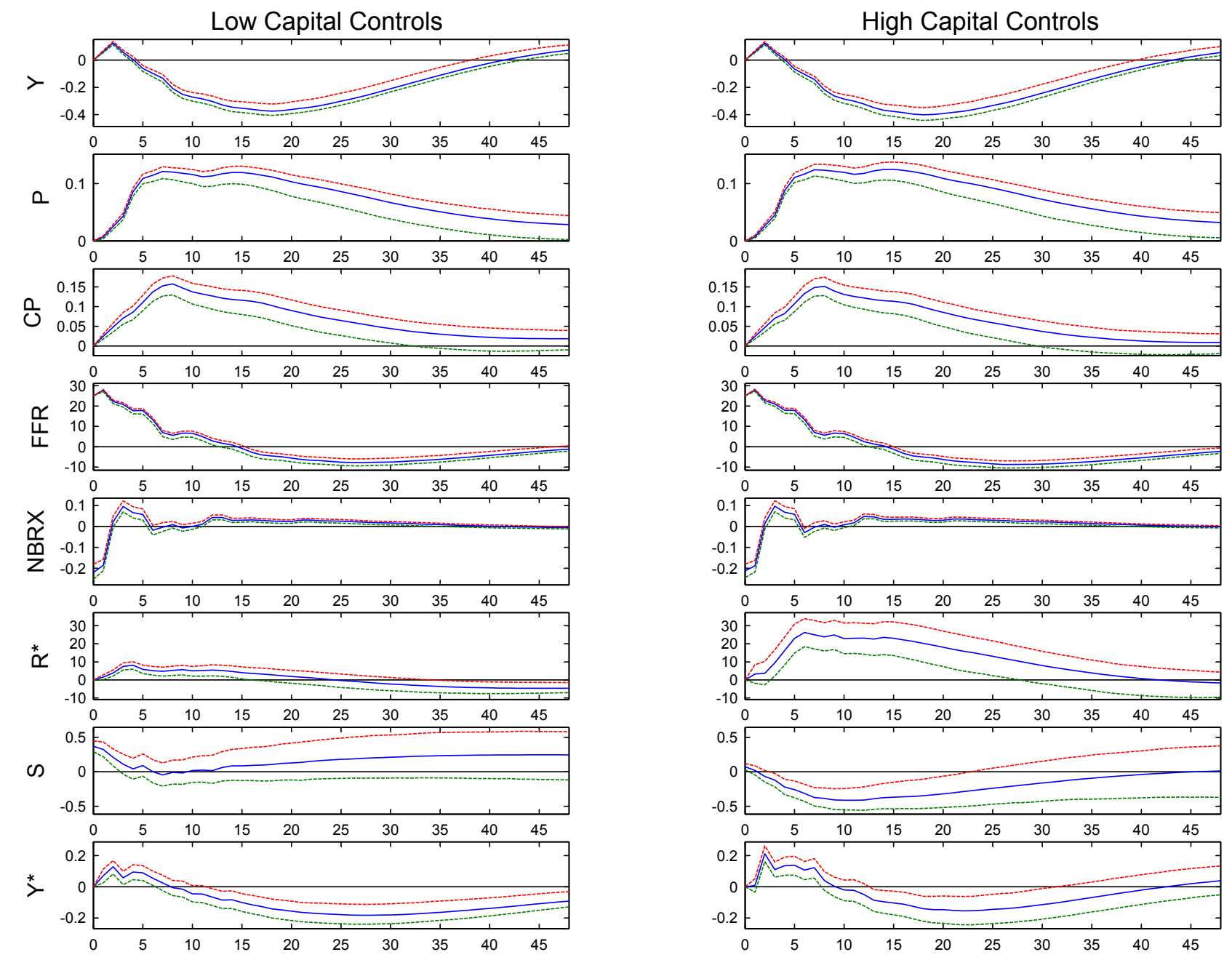
Comparison for the sub-period 1982-97
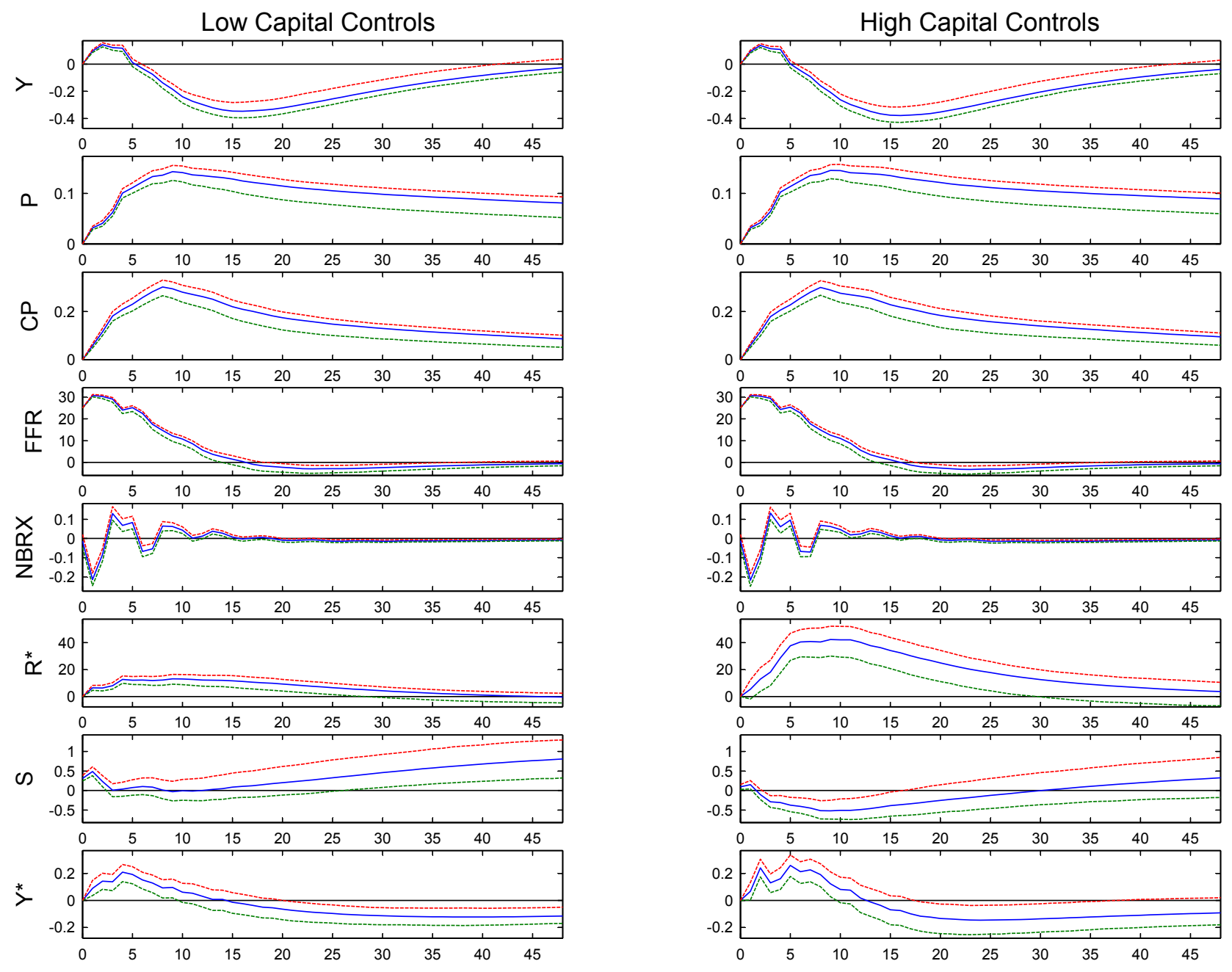


\section{Comparison for the sub-period 1983-98}
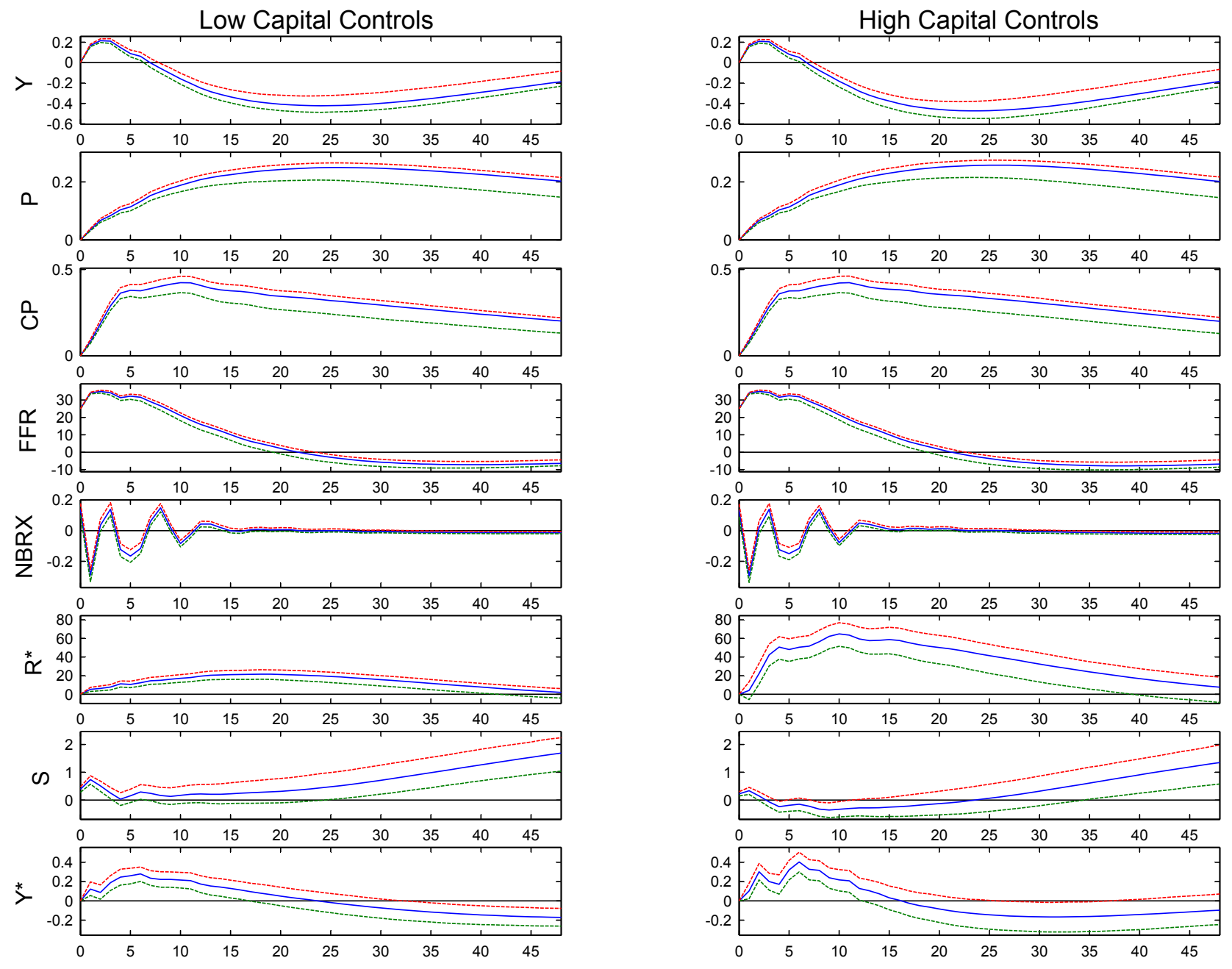
Comparison for the sub-period 1980-96
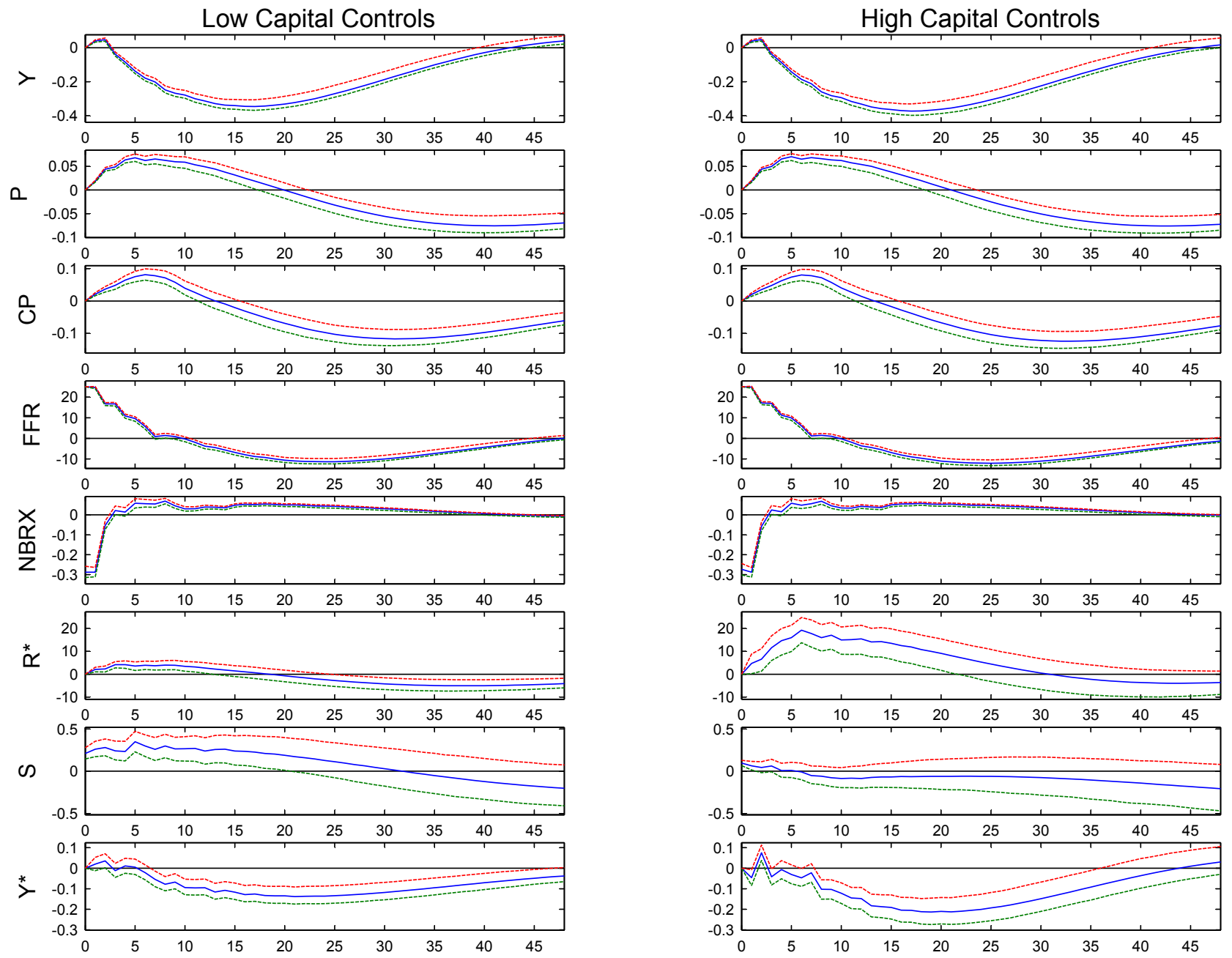
Comparison for the sub-period 1980-97
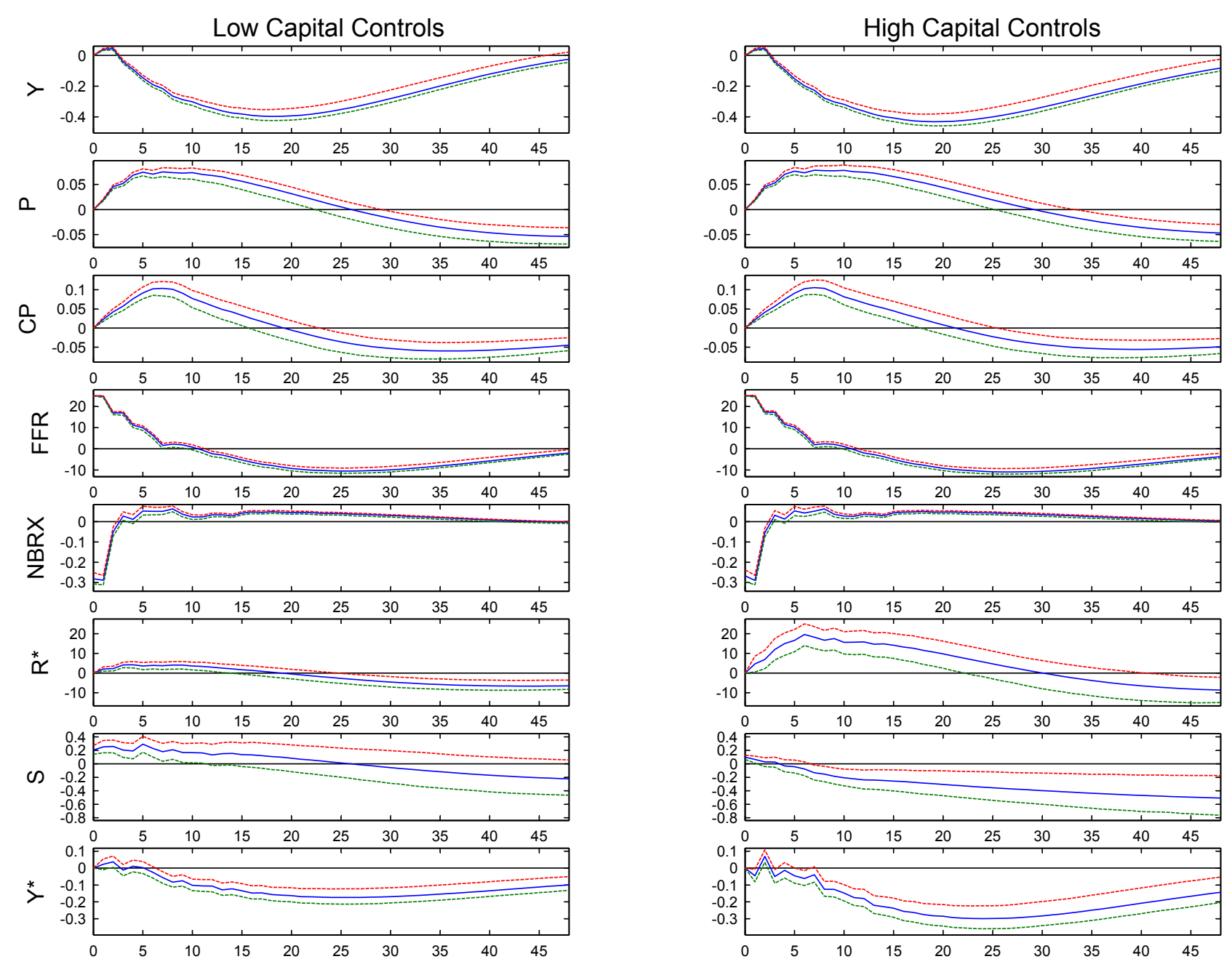


\section{Comparison for the sub-period 1980-98}
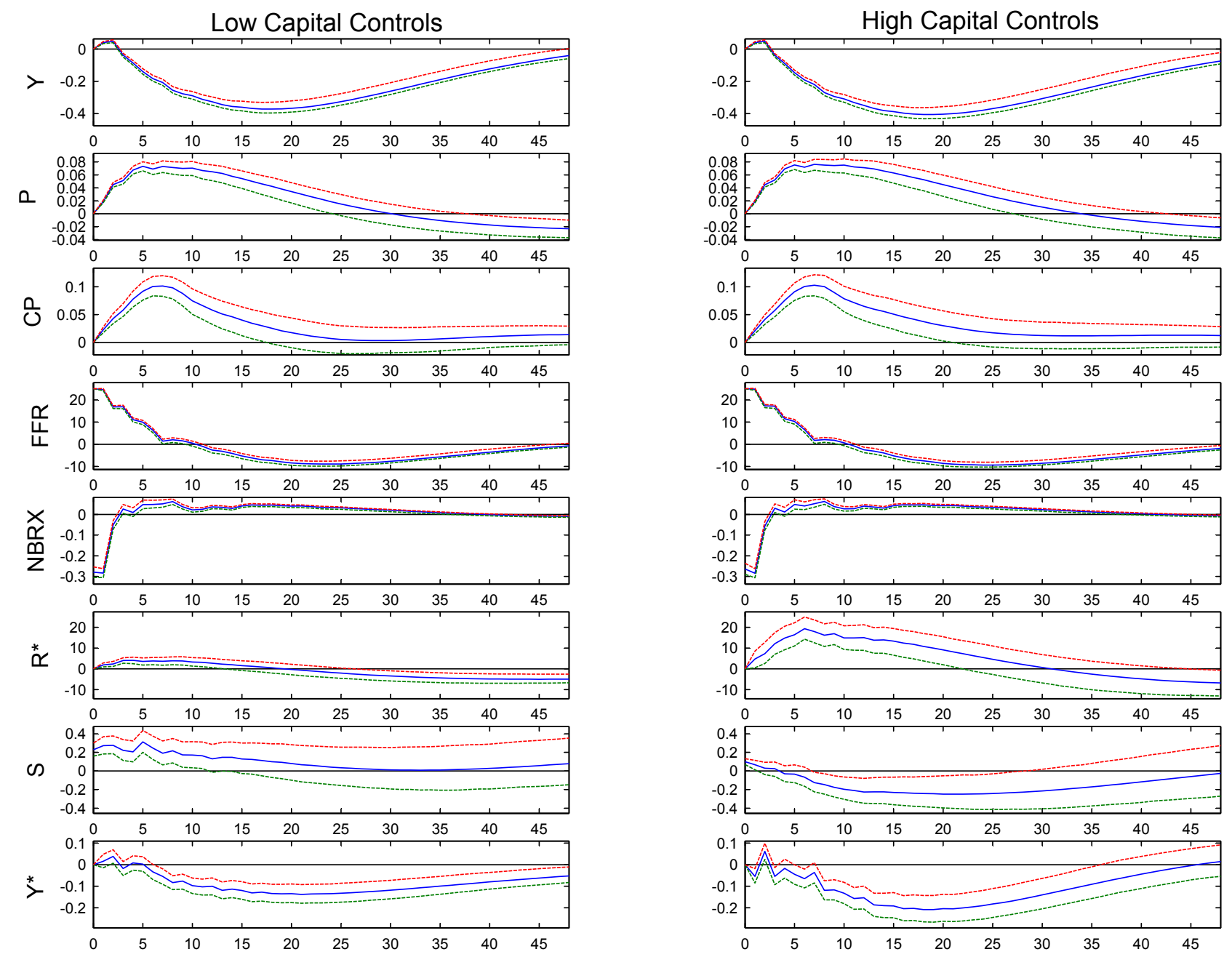